\title{
Direct electrochemical enzyme electron transfer on electrodes modified by self- assembled molecular monolayers
}

Yan, Xiaomei; Tang, Jing; Tanner, David Ackland; Ulstrup, Jens; Xiao, Xinxin

Published in:

Catalysts

Link to article, DOI:

10.3390/catal10121458

Publication date:

2020

Document Version

Publisher's PDF, also known as Version of record

Link back to DTU Orbit

Citation (APA):

Yan, X., Tang, J., Tanner, D. A., Ulstrup, J., \& Xiao, X. (2020). Direct electrochemical enzyme electron transfer on electrodes modified by self-assembled molecular monolayers. Catalysts, 10(12), [1458].

https://doi.org/10.3390/catal10121458

\section{General rights}

Copyright and moral rights for the publications made accessible in the public portal are retained by the authors and/or other copyright owners and it is a condition of accessing publications that users recognise and abide by the legal requirements associated with these rights.

- Users may download and print one copy of any publication from the public portal for the purpose of private study or research.

- You may not further distribute the material or use it for any profit-making activity or commercial gain

- You may freely distribute the URL identifying the publication in the public portal 


\title{
Direct Electrochemical Enzyme Electron Transfer on Electrodes Modified by Self-Assembled Molecular Monolayers
}

\author{
Xiaomei Yan, Jing Tang, David Tanner, Jens Ulstrup and Xinxin Xiao *D \\ Department of Chemistry, Technical University of Denmark, 2800 Kongens Lyngby, Denmark; \\ xiyan@kemi.dtu.dk (X.Y.); tangjing_12@163.com (J.T.); dt@kemi.dtu.dk (D.T.); ju@kemi.dtu.dk (J.U.) \\ * Correspondence: xixiao@kemi.dtu.dk
}

Received: 8 November 2020; Accepted: 10 December 2020; Published: 14 December 2020

\begin{abstract}
Self-assembled molecular monolayers (SAMs) have long been recognized as crucial "bridges" between redox enzymes and solid electrode surfaces, on which the enzymes undergo direct electron transfer (DET) - for example, in enzymatic biofuel cells (EBFCs) and biosensors. SAMs possess a wide range of terminal groups that enable productive enzyme adsorption and fine-tuning in favorable orientations on the electrode. The tunneling distance and SAM chain length, and the contacting terminal SAM groups, are the most significant controlling factors in DET-type bioelectrocatalysis. In particular, SAM-modified nanostructured electrode materials have recently been extensively explored to improve the catalytic activity and stability of redox proteins immobilized on electrochemical surfaces. In this report, we present an overview of recent investigations of electrochemical enzyme DET processes on SAMs with a focus on single-crystal and nanoporous gold electrodes. Specifically, we consider the preparation and characterization methods of SAMs, as well as SAM applications in promoting interfacial electrochemical electron transfer of redox proteins and enzymes. The strategic selection of SAMs to accord with the properties of the core redox protein/enzymes is also highlighted.
\end{abstract}

Keywords: self-assembled molecular monolayers; electron transfer; direct electron transfer; bioelectrocatalysis; oxidoreductase; gold electrode; metallic nanostructures

\section{Introduction}

Self-assembled molecular monolayers (SAMs) are surface monolayers that spontaneously bind to metal surfaces on which, for example, the unique metal-S bonding between metal and thiols offers a versatile pathway to tailor interfacial properties for electrochemical and bioelectrochemical applications [1-4]. Thiol SAMs on metal surfaces are core targets to provide an understanding of self-organization and interfacial interactions at the molecular level in biological systems $[5,6]$. Bigelow and associates were the first to demonstrate well-oriented SAMs adsorbed on a platinum wire [7]. However, SAMs did not attract much attention until Nuzzo and associates discovered disulfide monolayers on gold substrates in solution, as a phenomenon different from conventional Langmuir-Blodgett (LB) films [8]. Besides gold and platinum substrates, SAMs can also form on the surfaces of other metals including silver, copper, palladium, and mercury [9-14]. Gold is, however, the most extensively investigated because of its chemical inertness, relatively easy handling, and wide potential window, suitable for a range of electrochemical studies [1,15].

In parallel, the nature of the surface Au-S bond has been under intense focus over a number of years [1,2,4] and was recently overviewed [16,17]. In contrast to molecular $\mathrm{Au}(\mathrm{I})-\mathrm{S}(-\mathrm{I})$ complexes, the "aurophilic" effect arising from collective interactions among surface Au atoms leads to displacement 
of the $6 \mathrm{~s}$ Au electrons out of chemical reach and the filled $5 \mathrm{~d}$ electrons taking over in Au-S bonding. The Au-S bond on Au surfaces is thus an intriguing example of (very) strong, aurophilically controlled van der Waals binding in an $\mathrm{Au}(0)-\bullet S(0)$ gold(0)-thiyl bond.

Electron transfer (ET) reactions between an electrode surface and an oxidoreductase are one of the most important topics in bioelectrocatalysis [18-22]. For example, oxidoreductases possess redox/catalytic center(s) that catalyze the oxidation of fuels on a bioanode (e.g., glucose, fructose, lactate, and sulfite) [20,23-25], which can be assembled with a biocathode undergoing biocatalytic reduction reactions, typically dioxygen reduction, in enzymatic biofuel cells (EBFCs), allowing biopower generation [26-29]. The bioelectrochemical ET processes are classified into direct ET (DET) and mediated ET (MET) $[19,20,30]$. The MET-type system utilizes external and artificial redox mediators to shuttle the electrons between the electrode and the oxidoreductase, especially if the redox center(s) are buried deep inside the protein structure [31,32]. In DET-type systems, redox enzymes are able to communicate directly with the electrode surface if the redox cofactors/centers are spatially close to the electrode surfaces (generally less than $2 \mathrm{~nm}$ ), facilitating electron tunneling [33]. DET is thus a simpler mechanism by eliminating the need for external redox mediators, and it is therefore amenable to more detailed mechanistic analysis.

Oxidoreductase immobilization is crucial to improving electrode reusability and stability [19]. To achieve efficient DET, it is important to consider the detailed surface characteristics of both enzyme and electrode for favorable enzyme orientation, leading to minimized electron tunneling distance. A wide range of carbon or metallic supports have been employed for effective enzyme immobilization [25,28,34-37]. Physical adsorption and covalent bonding are most commonly used. SAMs have been introduced into bioelectrocatalysis to serve as a bridge for gentle protein/enzyme immobilization on gold or other metal surfaces $[36,38,39]$. SAM structures are determined by the $\mathrm{Au}-\mathrm{S}$ bond, the surface structure of the metal surfaces, lateral interactions, as well as the solvent and electrolytes [6]. Use of SAMs avoids the direct contact of enzyme and solid surfaces [40], mimicking the microenvironment in biological membranes. SAMs exhibit a variety of functional hydrophilic or hydrophobic terminal groups, such as carboxyl, hydroxyl, amino, and alkyl groups [41]. Frequently used alkanethiol and thiophenol molecules are summarized in Figure 1. In addition, the DET kinetics can also be governed by tuning the SAM molecular chain length, as the ET rate is strongly controlled by the tunneling distance [42-44]. As an emerging approach, protein engineering provides oxidoreductases directly with thiol residues, leading to controlled orientations either by direct protein thiol binding or by thioether bond formation with unsaturated maleimide [45].

Current density and enzyme loading can be promoted using nanostructured materials [3,44,46-48]. Among these, metallic nanomaterials exhibit excellent electronic conductivity and large surface area, with promising potential in improving the catalytic response and stability of redox enzymes [25]. Nanoporous gold (NPG), prepared via de-alloying Au alloys or electrodeposition, with three-dimensional porous architecture and a relatively uniform pore size, is a particular candidate for immobilizing enzymes in DET $[25,28,32,49,50]$. Moreover, gold nanoparticles (AuNPs) featuring a spherical nanostructure and large surface areas have been widely studied in bioelectrocatalysis [51-54]. The combination of SAMs and nanostructured gold offers new opportunities in bioelectrochemistry and has been extensively reviewed $[21,32,55]$, but only a few reviews cover SAMs on planar or porous gold electrodes for controlling enzyme orientation [3,19]. DET based on carbon electrode materials (carbon nanotubes, graphene-based materials) is another major parallel sector, beyond the scope of the present focused review but recently reviewed elsewhere [18,56-58].

In this review, we review recent studies of SAMs in the DET-type bioelectrocatalysis of both atomically planar and nanostructured gold electrode surfaces. Preparations of SAMs coupled with characterization techniques, such as electrochemical, microscopic, and spectroscopic methods, are first overviewed. The use of structurally versatile SAMs and suitable electrode nanostructure supports achieving well-defined orientation for DET is highlighted next. The redox proteins and enzymes to be discussed are organized as (i) heme-containing proteins, i.e., cytochromes (cyts), fructose dehydrogenase 
(FDH), cellobiose dehydrogenase (CDH), glucose dehydrogenase (GDH), and sulfite oxidase (SOx); (ii) blue copper proteins, i.e., azurin, copper nitrite reductase (CuNiR), bilirubin oxidase (BOD), and laccase (Lac); (iii) [FeS]-cluster hydrogenases, i.e., [FeFe]-, [NiFe]-, and [NiFeSe]-hydrogenase. This classification is warranted primarily by the different nature of the core ET cofactor, but also with the specific secondary and tertiary structures of the protein that envelopes the metallic or non-metallic catalytic sites. Conclusions and further perspectives are offered and discussed in the final section.

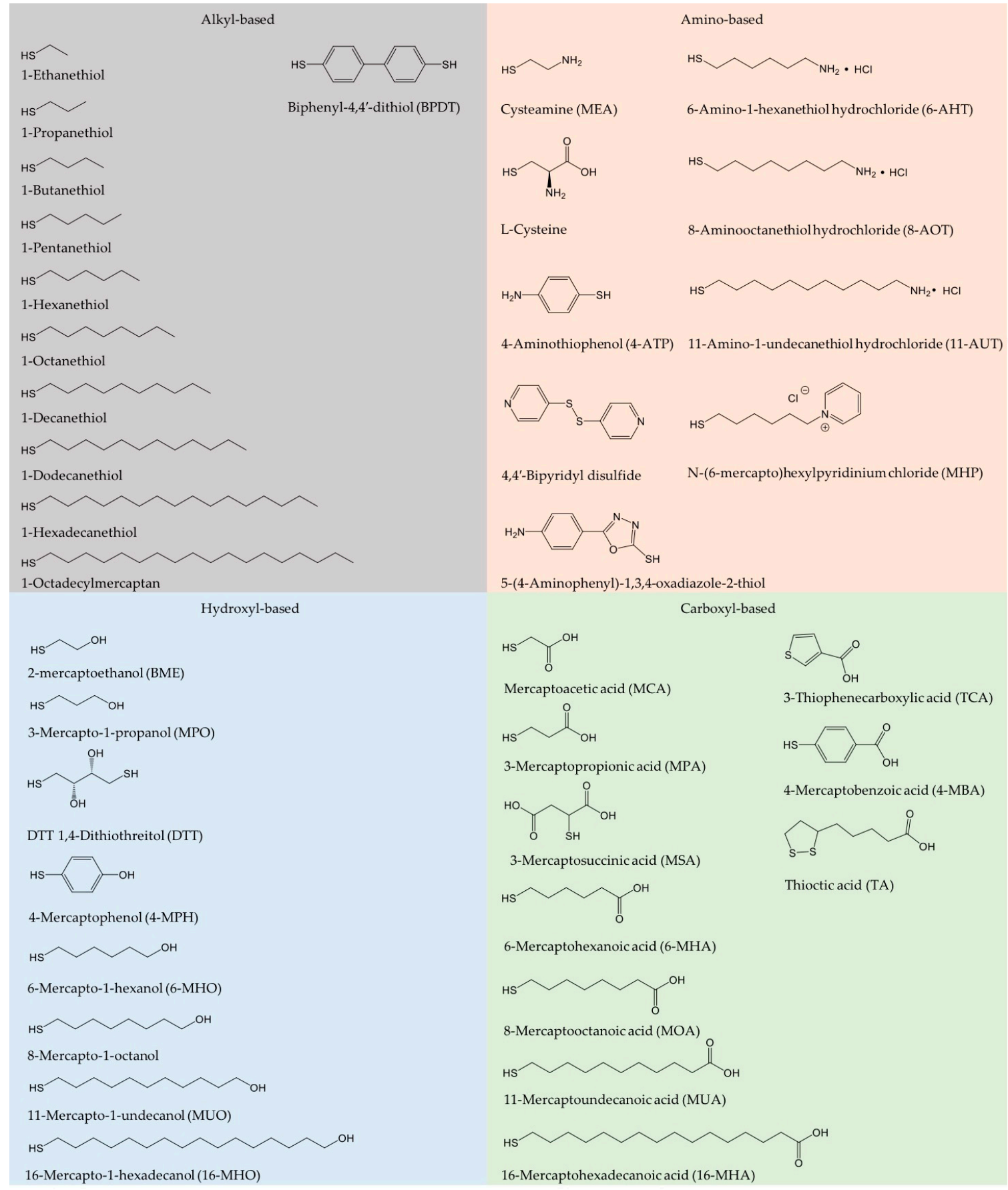

Figure 1. Frequently used alkanethiols and thiophenols in the formation of self-assembled molecular monolayers (SAMs) with alkyl, amino, hydroxyl, and carboxyl terminal groups. 


\section{Preparation and Characterization of SAM-Based Au- and Other Electrodes}

\subsection{Preparation of SAMs}

A great merit of SAM-forming thiols is that they form spontaneously on electronically soft metal substrates such as gold surfaces from liquid or vapor media under mild conditions [5,59]. Well-defined SAMs are formed by immersing the clean metal surface into a thiol solution, commonly ethanol or aqueous solution, for a certain period of time (hours to days), followed by washing with the same solvent. The quality of the SAMs is determined by the variety and concentration of thiol solution, temperature, soaking time, and the metal surface structure. Vapor deposition is also used to prepare SAMs, but the SAM morphology is here hard to control. Single-crystal, atomically planar gold electrodes are the best substrates to investigate the SAM properties, which can then be characterized using several in situ techniques including electrochemical scanning tunneling microscopy (in situ STM). Nanomaterials with porous structure and high surface area are also used as substrates $[40,60]$. It is noteworthy that a potential-assisted method to accelerate the SAM formation process has been developed $[9,61,62]$. The potential range is then a key parameter that strongly affects the quality of the SAMs, which can be evaluated simply by the surface coverage.

\subsection{Characterization Methods}

\subsubsection{Electrochemistry}

SAMs can be characterized by a range of methods, among which electrochemical methods have been widely reported [59]. Electrochemical methods involve cyclic (CV) and linear sweep voltammetry (LSV), and electrochemical impedance spectroscopy (EIS). CV of non-redox active SAMs, i.e., capacitive voltammetry, generally shows decreased double-layer capacitance after SAM adsorption on a metal surface. LSV and CV records the irreversible reductive (and oxidative) desorption of SAMs at a negative (or positive) potential. Reductive desorption is well suited to evaluating the surface coverage and the thermodynamic stability of the SAM Au-S units. The shape and position of the desorption peaks are sensitive to the crystalline surface structure and the SAM species. EIS can disentangle the ET resistance from the mass transfer or diffusion resistance. As noted, the ET resistance increases with increasing chain length because of the increased tunneling distance [63]. Electrochemical quartz crystal microbalance (EQCM) is an in situ technique, allowing real-time monitoring of the SAM adsorption process with high sensitivity to the mass changes on the electrode [59].

\subsubsection{Microscopy}

Electrochemical scanning probe microscopies (SPMs), especially STM and atomic force microscopy (AFM), have been extensively used to provide structural SAM properties at the single-molecule level. The principle of STM is based on the quantum tunneling effect. A bias voltage is applied across the metal support and the extremely sharp STM probe, generating tunneling currents, which are transformed to high-resolution conductivity images when the STM tip is scanned across the SAM-modified metal support. Zhang and associates have reported extensive in situ STM investigations using a wide range of alkanethiols on single-crystal gold [6,64-66]. In situ STM combined with electrochemical control can also directly map real-time SAM dynamics and structural features. In situ AFM has also attracted attention in bioelectrochemistry [67]. AFM records complex forces, mapping the structural information by allowing the tip to directly contact the redox protein/enzyme molecules. High-resolution STM has been employed to record the SAM thickness and molecular orientations. Contact angle (CA) measurement is a simple and straightforward method for monitoring the hydrophobic/hydrophilic properties of SAMs [1,5]. 


\subsubsection{Spectroscopy}

Various spectroscopic techniques are needed to map the complex interactions between SAMs and the metal support $[16,17]$. X-ray photoelectron spectroscopy (XPS) records the element composition and the chemical state of the SAMs. The high-resolution XPS spectra of S $2 p$ usually show a doublet at the binding energy ranging from 160 to $165 \mathrm{eV}$, attributed to the formation of the Au-S bond between alkanethiol molecules and the metal support. The functional SAM groups can be identified by Fourier-transform infrared spectroscopy (FTIR), and Raman spectroscopy can be used to detect structural changes in SAMs [68]. Surface plasmon resonance (SPR) spectroscopy is a powerful technique to measure the SAM thickness, showing a change in the tilt angle when the SAM thickness varies. Notably, the adsorption kinetics can be monitored online by SPR coupled with ellipsometry [62].

\section{SAMs and Electrochemical DET of Redox Proteins/Enzymes}

SAMs have received considerable early and recent attention as substrates for interfacial bioelectrochemical DET reactions, and a wide range of metalloproteins have been investigated in terms of catalytic mechanism and ET kinetics on various SAM-modified electrode surfaces. The redox active centers of protein/enzymes in DET can be roughly categorized into two major groups: metal-based (iron, copper and molybdenum centers etc.) [20,69-71] and non-metal-based (e.g., flavin adenine dinucleotide (FAD) and pyrrolo-quinoline quinone (PQQ)) centers [44,72,73]. Most, although not all, DET-capable enzymes harbor multiple redox centers, with internal ET relays via heme groups, copper clusters, or Fe-S clusters, which shuttle electrons between the electrode surface and the catalytic cofactors $[45,74,75]$. In this section, we overview recent studies where SAMs have been used in DET-type electrocatalysis and discuss how to obtain favorable orientations using versatile SAMs, as well as how to tune the interactions between the redox protein/enzyme and the SAM-modified electrodes. Redox proteins/enzymes which can be immobilized in well-defined orientations on SAM-modified supports are illustrated in Figure $2[4,15,19,32,64,67,70,76-81]$. We shall overview and discuss some selected examples from each of these enzyme classes in Sections 3.1-3.3.
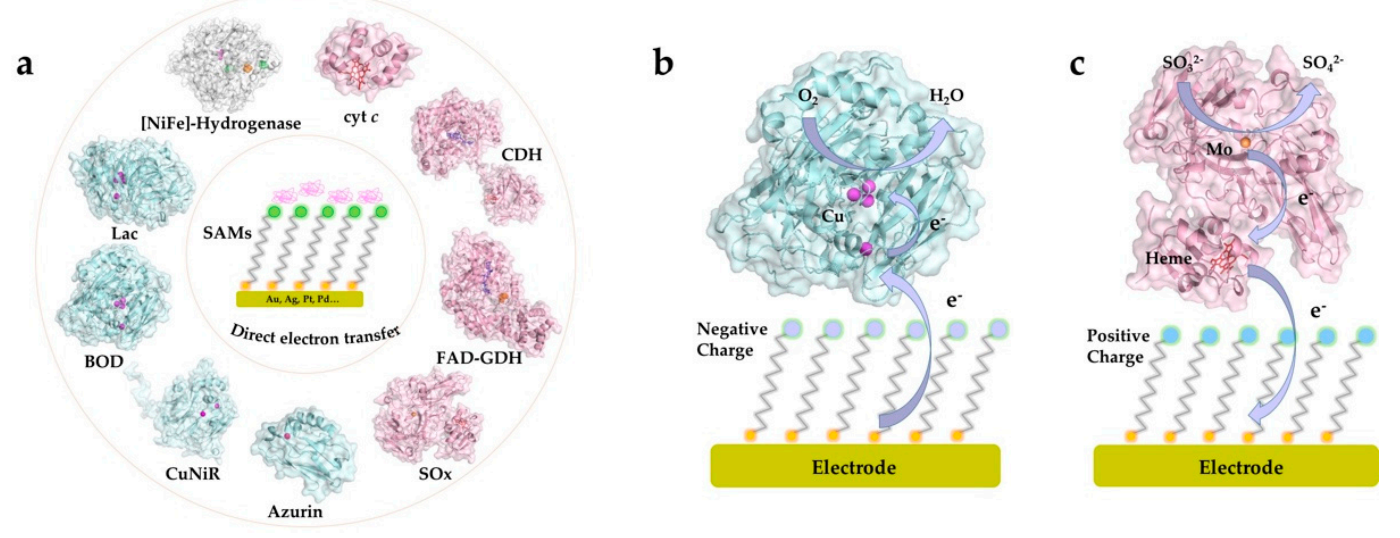

Figure 2. (a) Illustration of common proteins/enzymes capable of direct electron transfer (DET) on electrode modified by self-assembled molecular monolayers (SAMs). The proteins include: horse heart cytochrome $c$ (cyt c), PDB 1HRC; cellobiose dehydrogenase (CDH) from Neurospora crassa, PDB 4QI7; gamma-alpha subunit of FAD-dependent glucose dehydrogenase (FAD-GDH) from Burkholderia cepacia, PDB 6A2U; chicken liver sulfite oxidase (SOx), PDB 1SOX; Pseudomonas aeruginosa azurin T30R1, PDB 5I28; monomer of Achromobacter xylosoxidans copper nitrite reductase ( $A x \mathrm{CuNiR})$, PDB 1HAU; bilirubin oxidase from Myrothecium verrucaria (BOD), PDB 2XLL; laccase (Lac) from Trametes versicolor, PDB 1KYA; [NiFe]-hydrogenase from DesulfovVibrio Vulgaris Miyazaki F (DvMF), PDB 1UBU. Schematic view of representative DET processes of (b) mvBOD and (c) SOx on the electrode modified with negatively and positively charged SAMs, respectively. 


\subsection{Heme-Containing Proteins}

\subsubsection{Cytochrome $c$}

As an electrochemical paradigm redox metalloprotein target, cytochrome $c$ (cyt $c$ ) is a soluble heme protein extensively studied also as a model metalloprotein on thiol SAM surfaces [64,82-87]. Comprising 105 amino acid residues, cyt $c$ (horse heart, ca. MW: $12.4 \mathrm{kDa}$ ) is an electron transport protein largely present in eukaryotic cells [88]. Cyt $c$ is an ideal model system enabling an understanding of protein ET mechanisms in electrochemistry and homogeneous solution. The interfacial ET rate constant $\left(k_{a p p}\right)$ can be obtained based on the Laviron equation [89]. Electroreflectance spectroscopy (ER) has been utilized to obtain more accurate $k_{a p p}$ due to the elimination of the capacitive double-layer charging current [83]. Horse heart cyt $c$ is the most studied cytochrome, containing a number of positively charged lysine residues around the heme edge. Cyt $c$ docks electrostatically with natural partners including cyt $c$ oxidases/peroxidases. To immobilize cyt $c$, SAMs with carboxyl terminal groups are suitable due to favorable electrostatic binding [84]. Collinson and associates demonstrated that horse heart cyt $c$ shows similar orientations on the carboxyl terminated SAM-modified electrode for both covalent bonding and electrostatic adsorption, but covalent bonding led to more stable immobilization [85]. It was also noted that the formal redox potential $\left(\mathrm{E}^{\circ}\right)$ of electrostatically adsorbed horse heart cyt $c$ is shifted negatively due to the electrostatic interactions with the negatively charged SAM surface.

SAMs, consisting of a mixture of long-chain pyridine alkanethiols and short-chain alkanethiols, enhance the interfacial $k_{\text {app }}$ because of more favorable electronic coupling between cyt $c$ and the electrodes $[84,86]$ than for pure SAMs. The effect of lysine residues on interfacial ET was explored by substituting lysine residues at specific positions. Niki and associates reported that replacement of lysine-13 with alanine in rat cyt $c$ (RC9-K13A) showed a more than five-fold ET rate decrease compared with replacing lysine-72 and lysine-79 [90], which suggests that lysine-13 exhibits optimized coupling with the carboxyl SAM-modified electrode. Direct bonding to the heme group with axial pyridine or imidazole ligands onto the gold surfaces is another effective method for narrow orientation distribution of cyt $c[84,87]$. The tunneling distance-dependent ET was also investigated by surface-enhanced resonance Raman (SERR) spectroscopy, showing a declining signal with increasing SAM chain length from 2-mercaptoacetic acid to 16-mercaptohexadecanoic acid [91].

AuNPs enhance the interfacial ET rate of cyt $c$ in bioelectrocatalysis. Insertion of $3-4 \mathrm{~nm}$ coated AuNPs between cyt $c$ and the a SAM-modified $\mathrm{Au}(111)$-electrode surfaces was shown to increase $k_{a p p}$ by more than an order of magnitude [89] in spite of an ET distance increase exceeding $50 \AA$. This raises issues relating to the mechanism of the AuNP promotion even of simple ET processes, discussed in detail recently [92,93]. Engelbrekt and associates reported ultra-stable starch-coated AuNPs, enabling a clear redox signal of yeast cyt $c$ on AuNP-modified basal plane graphite (BPG) electrodes but no signals on bare BPG and $\mathrm{Au}(111)$ electrode [94].

Other cytochromes, such as cyt $b$ and cyt $c_{4}$, have also been investigated. Della Pia and associates reported that ET between the heme group in cyt $b_{562}$ and the $\mathrm{Au}(111)$ electrode can be promoted by replacing the original aspartic acid residue with a cysteine residue, which provided specific protein orientation through a Au-S bond [95]. Chi and associates studied the interfacial and intramolecular ET kinetics of di-heme Pseudomonas stutzeri cyt $c_{4}$ compared with horse heart cyt $c$ (Figure 3) [64]. In situ STM showed directly that the dipolar cyt $c_{4}$ is vertically oriented on the carboxyl SAM-modified $\mathrm{Au}(111)$ electrode (Figure 3c), resulting in intriguing asymmetric CVs. The authors could show that electrons were first transferred to the heme with the higher potential and then to the second, low-potential heme by fast intramolecular ET. Lisdat and coworkers reported extensive studies on a multilayered protein-enzyme system on SAM-modified gold electrodes [96-99]. For example, they described a sulfite oxidase/cyt $c$ (SOx/cyt $c$ ) multilayer system without polyelectrolyte, repeatedly incubating the prepared cyt $c$-modified Au electrode into a mixture of SOx/cyt $c$ solution and pure cyt $c$ solution [97]. 
A notable current density was observed even up to eight SOx/cyt $c$ layers, which could be explained by the direct electronic interactions between the two proteins.

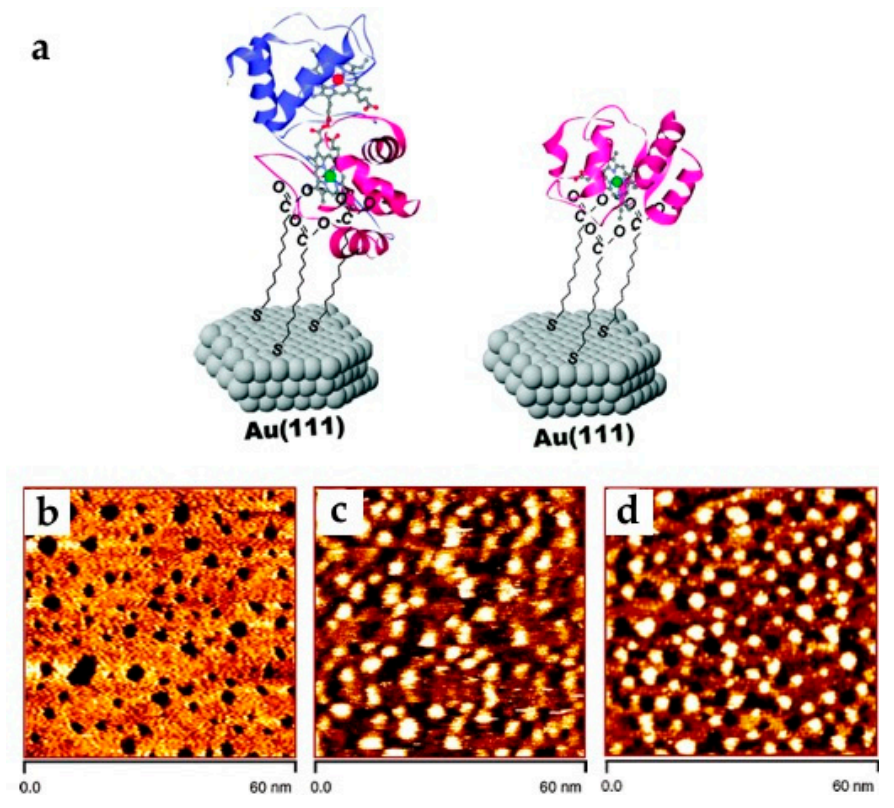

Figure 3. (a) Schematic illustration of $P$. stutzeri cyt $c_{4}$ (left) and horse heart cyt $c$ (right) on SAM-modified $\mathrm{Au}(111)$; in situ STM images of a $\omega$-mercapto-decanoic acid SAM-modified Au(111)-electrode surface (b) without protein as a reference, (c) with the two-domain P. stutzeri cyt $c_{4}$ vertically oriented (sharp roughly circular spots), and (d) horse heart cyt $c$ (sharp roughly circular spots) in $5 \mathrm{mM} \mathrm{pH} 7.0$ phosphate buffer under potential control in constant current mode; scan area, $60 \times 60 \mathrm{~nm}^{2}$ Reproduced with permission from [64]. Copyright 2010, American Chemical Society.

Overall, these reports highlight cyt $c$ as a core electron carrier enabling efficient ET between redox enzymes and the electrode surface across suitably chosen SAMs and along with the blue ET protein azurin as a case for characterization in unique detail, right down to the level of the single molecule. Many oxidoreductases furthermore rely on cytochrome domains or subunits as "built-in" ET relays between the catalytically active cofactor and the electrode surfaces and will be discussed in the following sub-sections [100].

\subsubsection{Fructose Dehydrogenase}

Although not approaching the degree of detail associated with the simpler ET proteins cyt $c$ and azurin, the molecular mechanistic mapping of several flavin dehydrogenases has reached an impressive level of detail over the last few years, represented by fructose dehydrogenase (FDH), CDH, and GDH in particular. The three enzymes display a common pattern, with a FAD catalytic center where fructose, cellobiose, and glucose, respectively, is oxidized, and an ET relays temporarily populated ET sites through which the liberated electrons are transmitted to the electrode surface. As the first FAD enzyme in our overview, Gluconobacter sp. FDH is a membrane-bound FAD-dependent oxidoreductase with a molecular mass around $140 \mathrm{kDa}[25,30]$. The protein holds three subunits: subunit I (67 kDa) contains a FAD cofactor, serving as the catalytic center for the two-electron oxidation of $\mathrm{D}$-fructose to keto-D fructose. Subunit II ( $51 \mathrm{kDa}$ ) has three heme groups with the formal potentials of $0.15,0.06$, and $-0.01 \mathrm{~V}$ vs. $\mathrm{Ag} / \mathrm{AgCl}$ electrode (sat. $\mathrm{KCl}$ ), respectively. Only two heme groups with the relatively lower redox potentials are proposed to participate in DET [30]. Subunit III (20 kDa) plays an important role in maintaining the structural integrity of the enzyme complex. A number of recent studies illustrate the employment of FDH for the development of biosensors and biofuel cells with high current density and operational stability [30,81,101,102]. 
The three-dimensional crystal structure, especially the enzyme surface properties, is essential for rational tuning of the redox enzyme immobilization. The detailed crystallography of FDH is still unclear, but homology models have helped to provide a clearer picture of intramolecular electron transfer (IET) [103]. Kano and associates constructed FDH variants with glutamine instead of the axial methionine ligands (M301, M450, or M578) of heme 1c, heme 2c, and heme 3c, respectively, illustrating that the ET pathway leads from M578 to M450 bypassing M301 [104]. Heme 1c with the highest formal potential of $0.15 \mathrm{~V}$ vs. $\mathrm{Ag} / \mathrm{AgCl}$ electrode was evaluated not to be involved in DET, whereas heme $2 c$ was identified as the ET bridge between FDH and the electrode surface. Heme $3 c$ with the lowest formal potential of $-0.01 \mathrm{~V}$ vs. $\mathrm{Ag} / \mathrm{AgCl}$ (sat. $\mathrm{KCl}$ ) was suggested as a bridge between FAD and heme $2 c$ in the IET process (Figure 4) [30]. In addition, the catalytic current density of FDH was dramatically increased by deleting the amino acid residues on the $\mathrm{N}$ - or C-terminus of subunit II $[30,105,106]$. The deletion not only promotes enzyme loading but also provides more opportunities for favorable orientations on the electrode surface. Some researchers reported that hydrophobic anthracene groups anchored on single-walled carbon nanotubes are favorable for enhanced catalytic activity and stability via the hydrophobic C-terminal region of subunit II [101,107]. These studies suggest that orientation and enzyme loading are crucial for controlling the catalytic activity in DET-type bioelectrocatalysis.

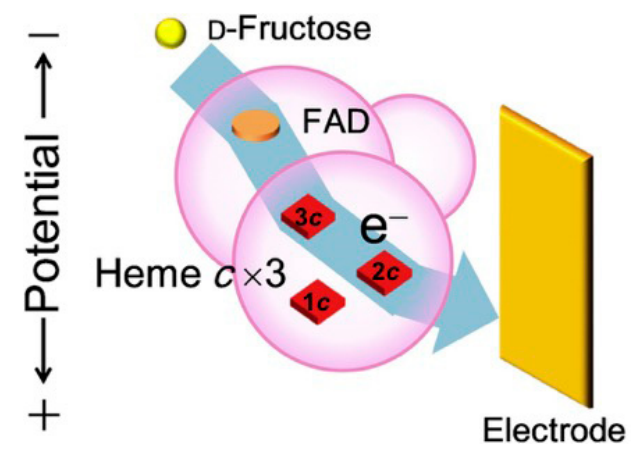

Figure 4. Proposed ET pathway from D-fructose to the electrode surface in the DET of FDH. The ET route involves FAD, heme $3 c$, heme $2 c$, but not heme $1 c$. Reproduced with permission from [30]. Copyright 2019, Elsevier.

Favorable FDH SAM immobilization rests on the following consideration: the isoelectric point (IEP) of FDH is 6.59, which means that FDH is overall positively charged in slightly acidic electrolyte [81]. Recent studies to improve the catalytic performance of FDH on various SAM-modified electrodes have been reported $[25,41,44,81]$. Bollella and associates reported extensive research on the catalytic activity of FDH on highly porous gold (h-PG) electrodes modified with 4-mercaptobenzoic acid (4-MBA), 4-mercaptophenol (4-MPh), and 4-aminothiophenol (4-APh) SAMs. The data showed that high bioelectrocatalytic activity and stability of FDH was only observed with -OH terminated SAMs [81], suggesting optimized enzyme orientation on this particular SAM. Negatively charged SAMs may help to favor FDH coverage due to preferred electrostatic interaction, but this is not necessarily the most favorable FDH orientation for DET. Murata and associates reached similar conclusions for FDH immobilized on 2-mercaptoethanol (MET) SAM-modified AuNPs [41]. Considering the importance of the gold nanostructure for the ET rate, the AuNP size is furthermore a crucial parameter. Kizling and associates synthesized 1.0 to $3.5 \mathrm{~nm}$ AuNP clusters functionalized with 1,6-hexanedithiol and 1-butanethiol for investigating the ET mechanism. A channel of "mediated" catalysis, i.e., electron "hopping", was observed for the smallest AuNP clusters around $1 \mathrm{~nm}$ with the half-wave potential close to the first oxidation potential of the AuNP at the edge of the HOMO-LUMO gap [44]. Such a mode accords with theoretical notions recently reported [92]. Siepenkoetter and associates reported the catalytic performance of covalently bonded FDH on NPG electrodes with varying pore sizes [25]. A large number of findings thus show that FDH has high affinity for well-defined SAM-modified electrodes with the polar but electrostatically neutral hydroxyl terminal group as the most efficient, 
indicating the importance of hydrophilicity of the electrode surface towards the mixed surface charge distribution of the FDH target enzyme. However, details of the underlying mechanism remain unknown.3.1.3. Cellobiose Dehydrogenase

The second FAD enzyme, cellobiose dehydrogenase $(\mathrm{CDH})$, is a versatile oxidoreductase for direct bioelectrocatalysis. $\mathrm{CDH}$ contains a catalytic dehydrogenase domain $(\mathrm{DH})$ harboring a FAD as the redox center and an ET cytochrome $b$ (CYT) domain to shuttle electrons from the FAD to the electrode surface $[23,45,108]$. The two domains are separated in the crystalline structure, but an integrated IET pathway can be opened through a flexible and hydrophilic amino acid linker between the catalytic and CYT domains [80]. This motif is encountered also for the molybdenum sulfite oxidases, cf. Section 3.1.4. $\mathrm{CDH}$ is extracted from the phyla Basidiomycota and Ascomycota, divided into class I, class II, and class III, respectively. Class III CDH from Ascomycota remains uncertain compared to class I and class II CDH [23].

The natural substrates of CDH mainly include cellulose, lactose, and glucose [108]. Class I CDH with short amino acid sequences shows direct, strongly $\mathrm{pH}$-dependent catalytic activity only in solutions with pH below 5.5 [23]. Harreither and associates reported extensive studies on class II CDH from Chaetomium attrobrunneum (CaCDH), Corynascus thermophiles (CtCDH), Dichomera saubinetii (DsCDH), Hypoxylon haematostroma (HhCDH), Neurospora crassa ( $\mathrm{NcCDH}$ ), and Stachybotrys bisbyi (SbCDH) [109]. $\mathrm{pH}$-dependent catalytic activity was observed for neutral and slightly alkaline electrolytes with cyt $c$ and 2,6-dichloroindophenol (DCIP) as electron acceptors. The different electrostatic environment in class I and II CDH reveals different optimal IET processes, with optimum IET in acidic electrolyte for class I CDH and neutral or slightly alkaline electrolyte for class II CDH [110]. Schulz and associates demonstrated turnover and non-turnover DET performance of $\mathrm{CDH}$ on polycrystalline gold modified with MUO or 6-MHO [23]. A clear catalytic current between the FAD and the electrode surface was reported. The midpoint potential of bound FAD cofactor was $-163 \mathrm{mV}$ vs. SCE at $\mathrm{pH} 3.0$, approximately $130 \mathrm{mV}$ less than that of the heme $b$ relay, leading to a much lower onset potential for lactose oxidation. The authors concluded that the tunneling distance between the FAD cofactor and the electrode was around 12-15 $\AA$, thereby allowing direct electrochemical communication. The authors also demonstrated that only class I CDH from Trametes villosa (TvCDH) and Phanerochaete sordida $\left(P_{S} \mathrm{CDH}\right)$ displayed DET activity, whereas no DET signal was observed for class II CDH from reconstructed Myriococcum thermophilum (recMtCDH) and reconstructed Corynascus thermophilus (recCtCDH) at low $\mathrm{pH}$.

The IEP of CDH (DH domain 5, CYT domain $\sim 3$ ) gives a negatively charged surface around the ET path exit, indicating that positively charged SAMs are suitable for favorable DET [110]. Lamberg and associates anchored Humicola insolens CDH on various SAMs with different terminal groups for investigating the effects of charge and hydrophobicity [111] and found that hydrophilic SAMs were favorable for high catalytic activities, with lower enzyme orientation variations than for hydrophobic SAMs. Tavahodi and associates reported a DET-type lactose biosensor of $P S C D H$ on polyethyleneimine (PEI)-coated AuNP electrodes (PEI@AuNP) [112]. PEI with positively charged amino groups not only optimized the orientation of $P_{s} \mathrm{CDH}$ on the electrode to increase the IET rate but also gave high enzyme stability and sensitivity. Bollella and associates reported a lactose biosensor based on DET of CtCDH on gold electrodes [113]. The authors demonstrated that BPDT SAMs with two thiol groups can be used to anchor metal NPs on a gold electrode surface by covalent bonding, showing the best ET rate on AuNPs/BPDT/Au electrode. A mediator-free $\mathrm{HiCDH} / \mathrm{Mv}$ BOD BFC using a positively charged MHP SAM for immobilization on AuNP-modified gold electrodes was also reported [114]. The half-life time, i.e., the time duration over which the activity decreased to half the initial value, was 13 and $44 \mathrm{~h}$ with $5 \mathrm{mM}$ glucose and $10 \mathrm{mM}$ lactose in neutral buffer solution, respectively. Hirotoshi and associates found an efficient ET process of Phanerochaete chrysosporium ( $P c \mathrm{CDH}$ ) on a mixed 11-AUT/MUOSAM-modified AuNP electrode [46]. Al-Lolage and coworkers addressed the catalytic performance and stability of MtCDH by introducing cysteine mutants (E522 and T701) on the protein surface (Figure 5) [45]. The cysteine mutant with a surface thiol group made it possible to form stable thioether bonds with maleimide groups via click-chemistry, thereby controlling the orientations of the $M t C D H$ mutant on the 
electrode surface and revealing efficient electrochemical glucose oxidation. Another example reported by Meneghello and associates clearly indicated that the DET-type bioelectrocatalysis of CDH is highly sensitive to the cysteine residues introduced at particular positions [115]. Experimental results also showed that divalent cations (i.e., $\mathrm{Ca}^{2+}$ and $\mathrm{Mg}^{2+}$ ) affect the IET kinetics $[23,115]$.

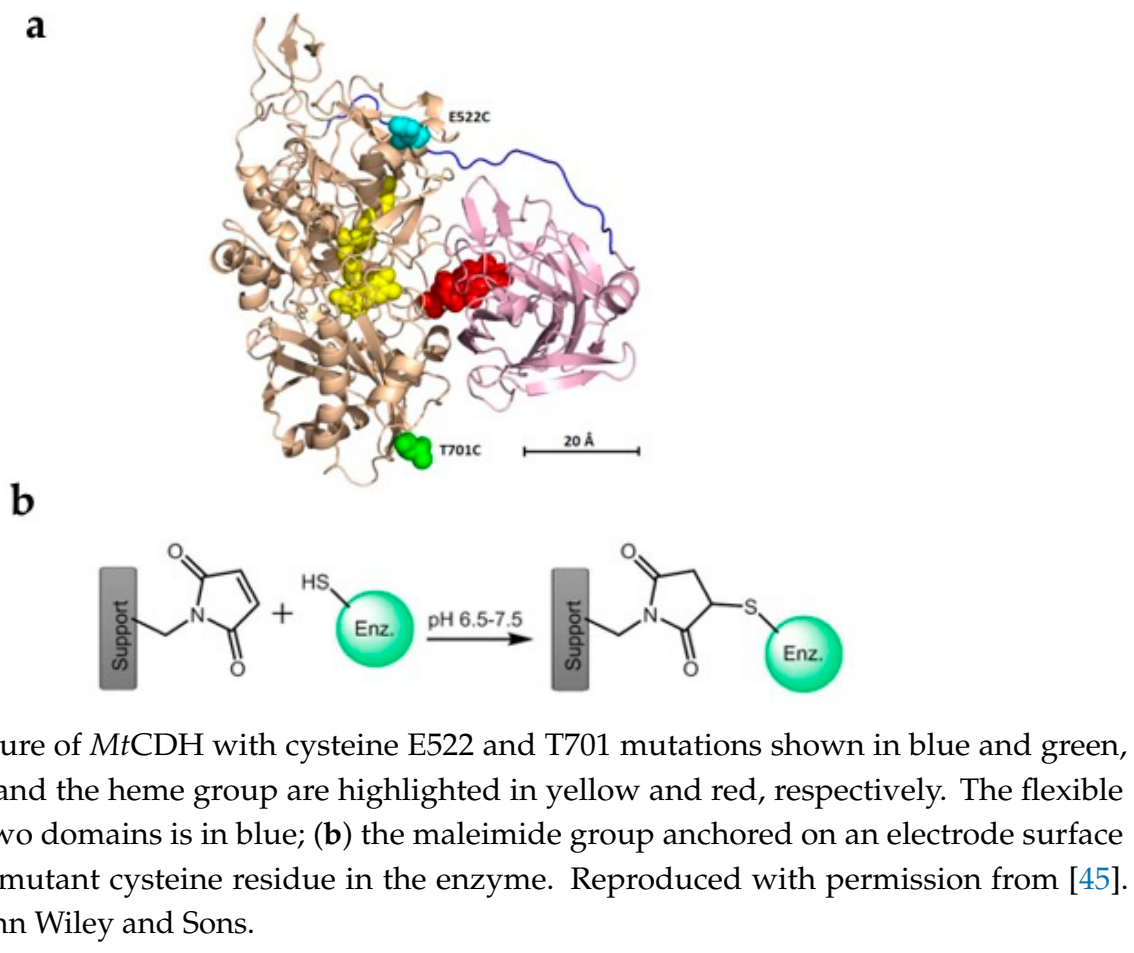

Figure 5. (a) Structure of $\mathrm{MtCDH}$ with cysteine E522 and T701 mutations shown in blue and green, respectively; FAD and the heme group are highlighted in yellow and red, respectively. The flexible chain linking the two domains is in blue; (b) the maleimide group anchored on an electrode surface can react with the mutant cysteine residue in the enzyme. Reproduced with permission from [45]. Copyright 2017, John Wiley and Sons.

\subsubsection{FAD-Dependent Glucose Dehydrogenase}

Our final FAD enzyme target, glucose dehydrogenase (FAD-GDH), is one of the most widely known dehydrogenases with a tightly bound cofactor, making it different from $\mathrm{NAD}^{+}$-dependent GDH. FAD-GDH has been extensively studied as an emerging alternative to glucose oxidase (GOx) due to its favorable DET capability, insensitivity to dioxygen, and the fact that no hydrogen peroxide is generated [116-119]. The structure of GDH is analogous to that of FDH, comprising three subunits: an FAD-dependent catalytic subunit, an ET subunit with three heme groups, and a small "hitch-hiker" protein used for the flexibility of the catalytic subunit into the periplasm $[116,120]$. The catalytic subunit harbors a $3 \mathrm{Fe}-4 \mathrm{~S}$ cluster close to the ET subunit protein surface, allowing efficient DET on the electrode without the need for mediators. Lee and associates demonstrated controlled DET of bacterial FAD-GDH from Burkholderia cepacia on three different SAM-modified electrodes, on which catalytic current density decreases with increasing SAM chain length [118]. A glucose biosensor based on FAD-GDH was reported recently by introducing a gold-binding peptide (GBP) for enzyme immobilization on a screen-printed electrode (SPE) [24]. GBP composed of 12 amino acids exhibiting a strong binding affinity to the gold electrode surface was fused to the enzyme terminus, thereby determining the enzyme orientation on the electrode. Around 10 times higher catalytic response toward $100 \mathrm{mM}$ glucose was observed with FAD-GDH-GBP/Au compared with normal GDH/Au.

A DET-type glucose biosensor could also be fabricated coupled with electrochemical impedance spectroscopy (EIS) [120]. Three variable-length thiols, dithiobis(succinimidyl hexanoate) (DSH), dithiobis(succinimidyl octanoate) (DSO), and dithiobis(succinimidyl undecanoate) (DSU), were employed to modify the electrode surface. Charge transfer resistance $\left(\mathrm{R}_{\mathrm{ct}}\right)$ was a key parameter reflecting the DET efficiency, with the lowest resistance when FAD-GDH was immobilized on DSH SAMs because of the shortest tunneling distance. In addition, the steady-state catalytic current density of FAD-GDH was dramatically increased on AuNPs assembled on the gold electrode [73,121]. Ratautas and associates reported high glucose oxidation activities of FAD-GDH extracted from 
Ewingella Americana without mediator [73,121]. They demonstrated that FAD-GDH immobilized on 4-ATP-modified AuNPs displayed higher catalytic activity and lower overpotential than on 4-MBA-modified electrodes. Notably, 4-ATP can be oxidized in neutral media and further converted to 4-mercapto-N-phenylquinone monoimine (MPQM), the quinone groups of which could bind covalently with primary amino groups of the enzyme, thereby enhancing the ET rate. The catalytic response was found to be positively correlated to the ratio of 4-ATP/4-MBA for electrodes modified by mixed thiol SAMs [121]. PQQ-dependent GDH is still another promising GOx candidate, widely utilized for glucose biosensors and biofuel cells $[35,95,96]$. Kim and coworkers prepared a glucose biosensor by immobilizing positively charged PQQ-GDH on MUA SAM-modified gold electrodes [122]. In this case, PQQ-GDH exhibited higher current density and detection sensitivity via electrostatic adsorption than via covalent bonding, due to less enzyme inactivation. Covalent bonding could thus enhance the interactions between enzyme and electrode surface, but the surface enzyme characteristics are the more critical factors that determine the electrochemical behavior.

\subsubsection{Sulfite Oxidase}

Sulfite oxidase (SOx) is another heme-containing redox enzyme which has been studied for a long time. Two kinds of SOx are mainly employed in DET-type bioelectrocatalysis: chicken liver, cSOx [123], and human, $h \mathrm{SOx}$ [124]. SOx acts by a principle resembling that of the FAD enzymes, with a catalytic center and an electronic relay, but also with some important differences. As a metalloprotein, the catalytic domain is composed of a pyranopterin molybdenum (Mo) cofactor effecting two-electron oxidation of sulfite to sulfate and connected to a N-terminal cytochrome $b_{5}$ (cyt $b_{5}$ ) domain by a flexible linker $[123,125]$. Although the crystallographic structure of $c S O x$ shows that the distance between the catalytic Mo domain and the cyt $b_{5}$ domain is more than $32 \AA$, rapid internal ET in DET-type bioelectrocatalysis is still observed [126], effected by a conformational change on the electrode surface via the flexible tether. This "on-off" switch enables cyt $b_{5}$ to be either adjacent or remote from the Mo cofactor $[70,127]$ in a gated ET mode, which is quite different from the rigidly bound ET relays in the FDH and GDH enzymes, but similar to the CDH operational mode.

The electrostatic surface charge distributions around both domains are complex and highlight the importance of subtle tuning of the electrode surfaces [124]. A positively charged SAM surface is favorable for immobilization of $h \mathrm{SO}$ via the Mo domain, directing the smaller heme domain towards the electrode surface. As noted, a similar pattern with a flexible linker connecting the catalytic and ET domain applies to $\mathrm{CDH}$ [80]; cf. Section 3.1.3. Sezer and associates investigated the catalytic activity of $h \mathrm{SOx}$ on a mixed SAM-modified silver electrode, showing a significantly increased SERR signal when increasing the ionic strength. High ionic strength is favored to shorten the distance between the Mo cofactor and the heme domain, thereby facilitating both intramolecular and interfacial ET. Wollenberger and associates reported other studies of the electrochemical behavior of $h \mathrm{SOx}$ [127-130]. In situ scanning tunneling microscopy and spectroscopy to single-molecule resolution has, finally been reported quite recently and disclosed intriguing patterns of tunneling via the Mo- and heme group redox centers [130]. AuNPs with a diameter less than $10 \mathrm{~nm}$ were covalently bonded on the MUA/MUO SAM-modified gold electrode, giving a significant enhancement of the interfacial ET rate of $h \mathrm{SO}$ [129]. The interfacial ET rate could be further increased by using SAMs with 3,3'-dithiodipropionic acid di(N-hydroxysuccinimide ester) (DTSP) thinner than MUA/MUO SAMs [128]. They also reported that the introduction of $\mathrm{BaSO}_{4}$ nanoparticles played a significant role in the DET-type bioelectrocatalysis of $h \mathrm{SOx}$. The electrochemical communication between the active sites of $h \mathrm{SO}$ and the electrode surface could be further enhanced by using a positively charged biopolymer. Kalimuthu and coworkers thus reported direct catalytic activity of $h \mathrm{SOx}$ on a chitosan-covered gold electrode [131]. Both non-catalytic redox signals corresponding to the heme group and catalytic signals in the presence of $4 \mathrm{mM}$ sulfite, on chitosan-covered MPA-, MSA-, and 4-MBA-modified electrodes were observed. However, there were no catalytic signals on MUA-based electrodes despite an observed non-turnover feature, highlighting the importance of rational SAM selection. 


\subsection{Blue Copper Proteins}

\subsubsection{Azurin}

Pseudomonas aeruginosa azurin is a simple blue copper protein that undergoes single-ET between the Type 1 copper atom and the electrode, now developed as a single-molecule "core" target [6,132-136], as for cyt $c$ characterized and mapped in unique detail. A hydrophobic patch and the disulfide group at opposite ends of the azurin molecule are both critical for well-defined orientations on the electrode. Chi, Ulstrup, Zhang and associates conducted extensive investigations of the electrochemical behavior of azurin $[39,43,51,137]$. In situ STM disclosed arrays of well-organized self-assembled azurin monolayers on single-crystal $\mathrm{Au}(111)$-electrodes mapped to single-molecule resolution [51]. Hydrophobic alkanethiol monolayers were employed for gentle immobilization by hydrophobic interactions with the hydrophobic patch of azurin [43]. Notably, exponential decay of the ET rate constant with increasing chain length was observed for chain lengths longer than six carbon atoms, reflecting a dual mechanism, with tunneling dominating for the longer chains [39]. The ET kinetics and redox mechanism of azurin have been analyzed theoretically at different levels, as discussed in detail elsewhere [6,138]. Inserting 3-4 nm coated AuNPs as for horse heart cyt $c$ [83] results in a 20-fold enhancement of $k_{a p p}\left(220 \pm 16 \mathrm{~s}^{-1}\right)$ for azurin compared with the AuNP-free system $\left(10.2 \pm 0.4 \mathrm{~s}^{-1}\right)$ [51]. Armstrong and associates compared the ET kinetics of azurin on the electrode modified with a synthetic $\{3,5$-diethoxy-4-[(E)-2-(4-ethylphenyl)vinyl]-phenyl $\}$ methanethiol or commercial- $\mathrm{CH}_{3}$ terminal alkanethiol [139]. The front hydrophobic ethyl group of SAMs served as the protein-binding bridge on the surface, yielding a very fast ET rate with a $k_{\text {app }}$ over $1600 \mathrm{~s}^{-1}$.

\subsubsection{Copper Nitrite Reductase}

A common feature of the blue multi-copper oxidases is a blue $T_{1}$ center for the electron inlet and a $T_{\text {II }}$ or combined $\mathrm{T}_{\text {II }} / \mathrm{T}_{\text {III }}$ catalytic center for the electron "outlet" in the catalytic process (nitrite, or, dioxygen reduction). Such an electrochemical mode of action is only feasible via an efficient (short) intramolecular ET channel. This feature has been mapped in considerable detail for three blue copper enzyme classes, the copper nitrite reductases, bilirubin oxidases, and the laccases. The trimeric blue copper nitrite reductase $(\mathrm{CuNiR})$ is crucial in the global nitrogen cycle, catalyzing the single-electron reduction of nitrite to nitrogen monoxide [140]. CuNiR effects direct bioelectrocatalysis, including an ET relay $\left(\mathrm{Cu}_{\mathrm{I}}\right)$ and a catalytic site $\left(\mathrm{Cu}_{\mathrm{II}}\right)$ in each monomer. Ulstrup and associates reported DET-based electrocatalysis of CuNiR from Achromobacter xylosoxidans ( $A x \mathrm{CuNiR}$ ) on a cysteamine SAM-modified $\mathrm{Au}(111)$ electrode [141]. In situ STM displayed single $A x \mathrm{CuNiR}$ molecules but, intriguingly, only in the presence of nitrite substrate. Further, the combination of varying alkanethiols with charged, neutral, hydrophilic, and hydrophobic properties showed that mixed hydrophilic/hydrophobic SAMs were the most favorable for facile $A x \mathrm{CuNiR}$ electrocatalysis [142]. In situ AFM is also reported and disclosed $A x \mathrm{CuNiR}$ conformational changes during catalytic reaction [67], with the apparent height of $A x \mathrm{CuNiR}$ rising from $4.5 \mathrm{~nm}$ in the resting state to $5.5 \mathrm{~nm}$ in the nitrite reduction state in the presence of nitrite.

\subsubsection{Bilirubin Oxidase}

Bilirubin oxidase (BOD) is another well-known blue multicopper oxidase class containing four copper centers $\left(T_{1}, T_{2} / T_{3}\right)$, catalyzing the dioxygen reduction reaction (ORR) into water in four-electron direct bioelectrocatalysis $[75,96]$. The blue $T_{1}$ center has a copper atom located closed to the protein surface for accepting electrons from the natural electron donor (bilirubin) or an electrode. The external electrons are relayed via a short ligand-bound intramolecular peptide bridge to the $T_{2} / T_{3}$ center, where ORR takes place. Target BODs are mainly from Myrothecium verrucaria (MvBOD) [26,29,75,143-145], Trachyderma tsunodae (TtBOD) [146], Bacillus pumilus (BpBOD) [147], and Magnaporthe oryzae (MoBOD) [148]. Single-crystal gold electrodes modified with $-\mathrm{NH}_{2},-\mathrm{COOH}$, $-\mathrm{OH}$, and $-\mathrm{CH}_{3}$ terminated SAMs have been studied and show that negatively charged SAMs are favorable for proper $M v B O D$ orientations due to the highly positively charged region close to the $\mathrm{T}_{1}$ 
center [42]. $\mathrm{E}^{\circ}$ values of $\mathrm{T}_{1}\left(0.69 \mathrm{~V}\right.$ vs. NHE) and $\mathrm{T}_{2} / \mathrm{T}_{3}(0.39 \mathrm{~V}$ vs. NHE) in $T t \mathrm{BOD}$ have been observed under aerobic conditions [146], but $\mathrm{E}^{\circ}$ of the $\mathrm{T}_{2} / \mathrm{T}_{3}$ centers drops to $0.36 \mathrm{~V}$ vs. NHE in the resting state of the enzyme, indicative of an IET pathway from $\mathrm{T}_{1}$ to $\mathrm{T}_{2} / \mathrm{T}_{3}$ triggered by the ORR process.

Characterization of enzyme loading and conformation on the electrode is crucial [149]. Lojou and associates studied the adsorption of $\mathrm{MvBOD}$ on both positively $\left(\mathrm{NH}_{3}{ }^{+}\right)$and negatively $\left(\mathrm{COO}^{-}\right)$charged SAM-modified electrodes with no significant difference in enzyme loading as disclosed by surface plasmon resonance (SPR) spectroscopy [26]. DET and MET processes were found to dominate on the $\mathrm{COO}^{-}$and $\mathrm{NH}_{3}{ }^{+}$surfaces, respectively, consistent with the positively charged surroundings of the $\mathrm{T}_{1} \mathrm{Cu}$ [26]. Polarization-modulated infrared reflection absorption spectroscopy (PMIRRAS) showed strong electrostatic interactions between the negatively charged SAMs and the positively charged $M v B O D$ surface near the $\mathrm{T}_{1} \mathrm{Cu}$ [26]. PMIRRAS and SPR ellipsometry were jointly used to demonstrate the effect of electrostatic interactions on the enzyme adsorption, catalytic performance, and stability of $\mathrm{MvBOD}$ at four different $\mathrm{pH}$ values (Figure 6) [75]. The dipole moment of the enzyme is distinct at different $\mathrm{pH}$ levels, showing a direction towards the $\mathrm{T}_{1}$ center in neutral or slightly acidic electrolytes but significantly shifted in the strongly acid electrolyte (Figure 6a). This accords with the different charge distributions at the $\mathrm{T}_{1} \mathrm{Cu}$ center. PMIRRAS spectra showed the amide $\mathrm{I}\left(\mathrm{ca} .1680 \mathrm{~cm}^{-1}\right.$ ) and amide II (ca. $1550 \mathrm{~cm}^{-1}$ ) peaks, related to vibrational C=O and N-H modes in MvBOD, respectively, see Figure $6 \mathrm{~b}$. The wavelengths of the two peaks remained unchanged upon enzyme immobilization, which suggests that the secondary structure of the MvBOD is retained. In addition, amide I/amide II ratios were similar at different $\mathrm{pH}$ levels, further indicating that the orientations of MvBOD were independent of $\mathrm{pH}$.
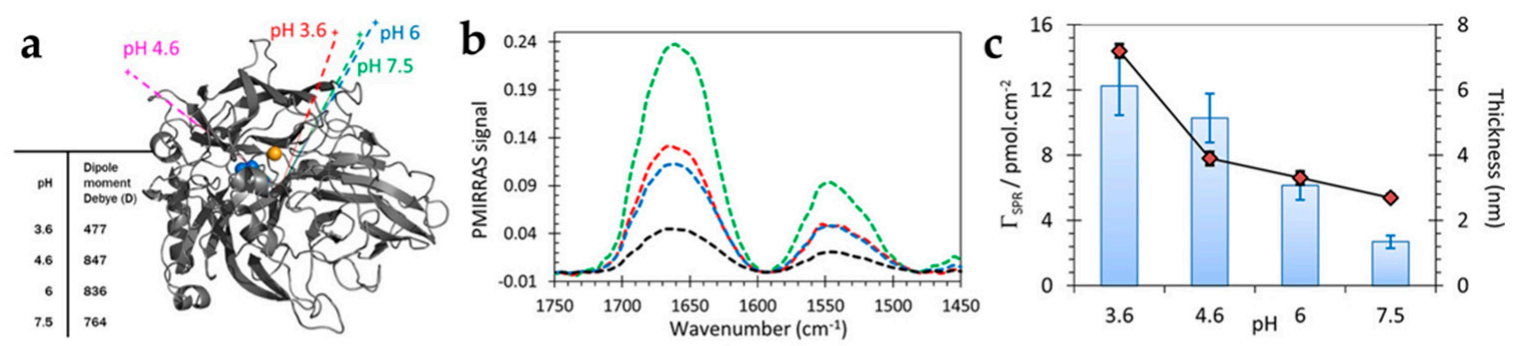

d
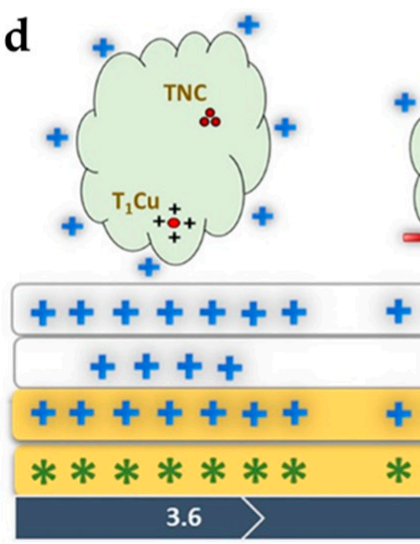

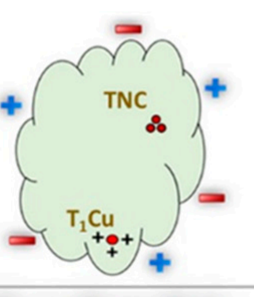

$=+a+c$
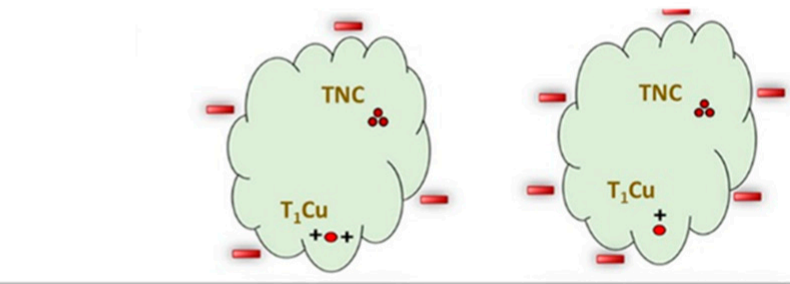

Global charge

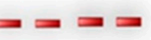

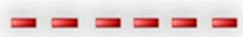
$+4+$ nearCuT1 $+4$ $t+t+t+$ 4-ATP SAM $+4+$ ******* ******* 6-MHA SAM = * $=*$

Figure 6. (a) $\mathrm{Mv} \mathrm{BOD}$ structure and dipole moments in the $\mathrm{pH}$ range 3.6 to 7.5 . $\mathrm{CuT}_{2} / \mathrm{T}_{3}$ contains three copper atoms marked in blue and $\mathrm{CuT}_{1}$ with a single copper atom marked in gold; (b) PMIRRAS signals of MvBOD-modified bioelectrodes with 6-MHA SAM; (c) Enzyme coverage ( $\Gamma$ ) and enzyme layer thickness at different $\mathrm{pH}$ recorded by SPR ellipsometry; (d) Cartoon illustration of the charge distributions of $\mathrm{MvBOD}$ at different $\mathrm{pH}$ levels, with the $\mathrm{CuT}_{1}$ center, as well the 6-MHA and 4-ATP SAM-modified electrode surfaces. The neutral electrode surface is indicated with green stars. Reproduced with permission from [75]. Copyright 2018, American Chemical Society. 
Enzyme loading, critical to catalytic activity, declines as $\mathrm{pH}$ increases (Figure 6c [75]). The authors demonstrated that MvBOD on a negatively charged 6-MHA SAM-modified electrode does not form a saturated monolayer at $\mathrm{pH} 7.5$ but possibly more than a single monolayer at $\mathrm{pH}$ 3.6. The electrostatic interactions between enzyme and SAMs thus not only strongly affect the enzyme adsorption, the dipole moment of the enzyme, and the charge around the $T_{1}$ center, but they also determine the enzyme orientation and catalytic rate (Figure 6d). Gholami and associates immobilized MvBOD on a gold microfilm by electropolymerization of TCA [150]. Molecular dynamics simulation has provided a more comprehensive understanding of $M v B O D$ in DET-type bioelectrocatalysis [151]. In particular, $M v B O D$ showed various orientations reflecting wide charge distributions, representing a "back-on" and "lying-on" state on positively and negatively charged electrodes, respectively.

Nanostructured gold surfaces are expected to improve the DET current density of BOD [29]. However, the apparent and real current densities normalized to the geometric and real gold surface area, respectively, should be distinguished. In comparison to FDH on $1 \mathrm{~nm}$ AuNPs [44], this is particularly important when the gold nanostructures are of larger size than BOD. Pankratov and associates investigated the size effect of sub-monolayer AuNPs (diameter: 20, 40, 60, and $80 \mathrm{~nm}$, significantly larger than $\mathrm{Mv} \mathrm{BOD}$ ) on the bioelectrocatalytic performance of $\mathrm{Mv} \mathrm{BOD}$ [152]. Although the apparent ORR current density increased with increasing size from 20 to $80 \mathrm{~nm}$ (proportionally to the real surface area), similar values $\left(15 \pm 3 \mathrm{uA} \mathrm{cm}^{-2}\right)$ for the real current density were obtained. This can be explained by the fact that the ET rate constant is independent of the AuNP size in this case, with similar values of $10.3 \pm 0.5 \mathrm{~s}^{-1}$ and $10.7 \pm 0.3 \mathrm{~s}^{-1}$ for the $M v$ BOD-based bioelectrode with and without AuNPs, respectively. Siepenkoetter and associates immobilized MvBOD on NPG using diazonium grafting coupled with an MPA SAM [28]. NPG electrodes with average pore sizes between 9 and $62 \mathrm{~nm}$ were finally investigated. The maximum apparent ORR current density was achieved with 10 and $25 \mathrm{~nm}$ pores, slightly larger than the enzyme and likely due to a compromise between the real gold surface area and enzyme loading, but similar real current densities were registered for these pore sizes.

\subsubsection{Laccase}

The laccases (Lac) constitute a third important member class of the multicopper oxidases, containing $T_{1}$ and $T_{2} / T_{3}$ centers $[27,153,154]$. Similar to BOD, $T_{1}$ and $T_{2} / T_{3} C u$ centers act as electron acceptance and ORR centers, respectively. $\mathrm{E}^{\circ}$ of the $\mathrm{T}_{1}$ center from tree Lac is lower than those from fungal Lac, varying in the range 300 to $800 \mathrm{mV}$ vs. NHE [155]. Bioelectrocatalysis of fungal Lac has been extensively investigated [156]. SAMs with specific functional groups favor productive orientations of Lac at the electrode surface. Thorum and associates reported that the overpotential of ORR of Lac from Trametes versicolor (TvLac) could be decreased by employing an anthracene-2-methanethiol SAM on gold. The aromatic anthracene presumably penetrates into the hydrophobic pocket close to the $T_{1}$ center, facilitating DET [157]. Climent and associates investigated the DET-type catalytic activity of three different Lacs (Coprinus cinereus (CcLac), Myceliophthora thermophila (MtLac), and Streptomyces coelicolor (ScLac)) [38]. In situ STM enabled single-molecule understanding of enzyme-electrode electronic interactions and the IET process on well-defined $\mathrm{Au}(111)$ surfaces with various SAMs. MPA SAMs with the carboxyl terminal group was best for CcLac, while alkyl and amino SAMs were most suitable for ScLac. No catalytic signal was found for MtLac on any SAMs. As for AxCuNiR, single-molecule in situ STM contrasts were observed only in the presence of enzyme substrate, nitrite, and dioxygen, respectively. Traunsteiner and coworkers exploited DET-type bioelectrocatalysis of TvLac using diluted MPA SAMs and a linker molecule of thiolated veratric acid (tVA) that could approach the $\mathrm{T}_{1}$ site [158]. Optimal catalytic activity was shown when the tVA and MPA SAMs were mixed uniformly, whereas the catalytic activity decreased dramatically due to the aggregation of tVA. Molecular dynamics simulations also showed that the positively charged SAMs were more favorable for the DET of TvLac, with a narrow orientation distribution. 
A recent study evaluated Thermus thermophilus (TtLac), exhibiting a methionine rich domain. Figure 7 shows the detailed three-dimensional structure and electrostatic charge distributions of the surface amino acid residues of $T t \mathrm{Lac}$ [69]. The $\mathrm{T}_{1}$ center, used for transferring electrons to an external electrode, showed a negatively charged zone. Gold electrodes modified with negatively $\left(-\mathrm{COO}^{-}\right)$, uncharged $(-\mathrm{OH})$, and positively charged groups $\left(-\mathrm{NH}_{3}{ }^{+}\right)$were adopted, with the highest catalytic current on the positively charged electrode and with no or only weak catalytic signals on the negatively charged and uncharged electrodes, respectively [69]. Nanostructured materials have been developed recently to optimize the Lac orientation. NPG modified with 4-ATP SAM could increase the catalytic performance and stability at high temperatures [159]. Cristina and associates reported that AuNPs (particle size: $5 \mathrm{~nm}$, comparable to the size of the enzyme) served as electronic bridges, thus promoting DET with a heterogeneous ET rate constant over $400 \mathrm{~s}^{-1}$ [54]. Nanostructured electrodes consisting of low-density graphite (LDG) and gold nanorods (AuNRs, average length: $31 \pm 6 \mathrm{~nm}$, width: $5 \pm 1 \mathrm{~nm}$ ) have, finally, been prepared to orient Lac for improved ORR [27].
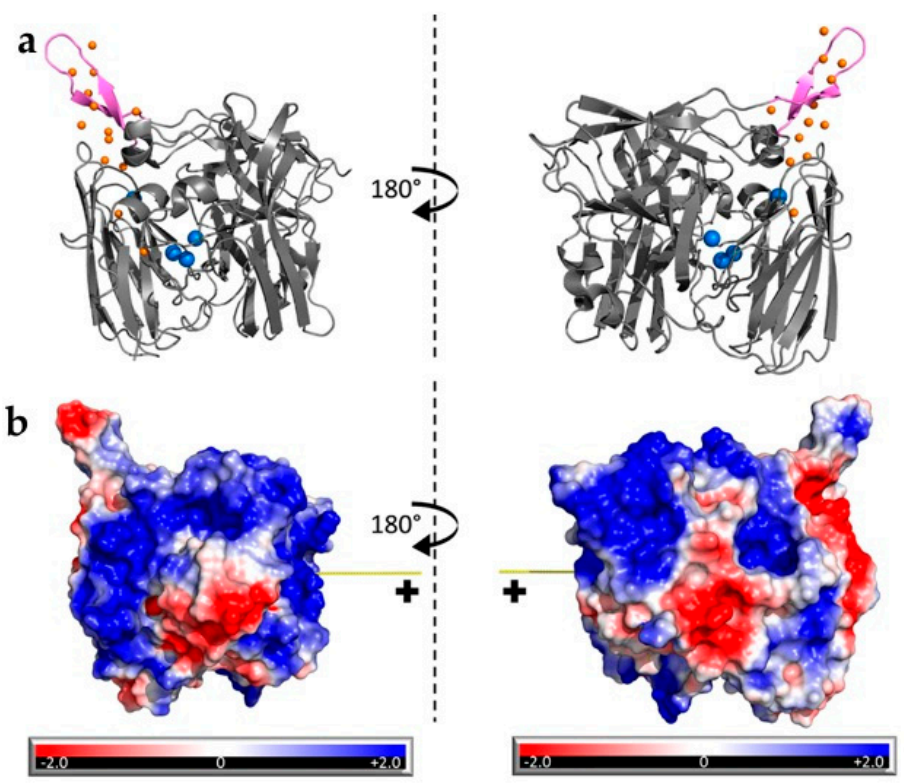

Figure 7. (a) Model structure of TtLac (PDB 2XU9) showing the hairpin domain (magenta), the $\mathrm{T}_{1}$ and $\mathrm{T}_{2} / \mathrm{T}_{3} \mathrm{Cu}$ centers (blue spheres) and all Met sulfurs (yellow spheres); (b) Electrostatic potentials at the surface of $T t \mathrm{Lac}$ in the same orientation as in the top panel at $\mathrm{pH}$ 5: positive charges in blue, negative charges in red, and neutral in white. The positive end of the dipole moment vector is shown as a yellow stick. Reproduced with permission from [69]. Copyright 2020, American Chemical Society.

\section{3. [FeS]-Cluster Hydrogenases}

Hydrogenases are a class of [FeS] cluster-based metalloproteins which reversibly catalyze the two-electron reactions of dihydrogen oxidation and evolution [71,74]. The commonly reported membrane-bound hydrogenases can be classified based on their intrinsic catalytic cofactors ([FeFe], [NiFe], and [NiFeSe]), where hydrogen conversion is combined with [FeS] electron relay to accomplish the entire ET process. It has been reported that the smallest [FeFe]-hydrogenase $\mathrm{CrHydA} 1$ isolated from Chlamydomonas reinhardtii exhibits dioxygen insensitivity and shows high catalytic activity in dihydrogen evolution [160]. The conditions of immobilized [FeFe]-hydrogenase CrHydA1 on a SAM-modified gold electrode were characterized by in situ surface-enhanced infrared absorption spectroscopy (SEIRAS) and SPR spectroscopy [160]. Madden and associates investigated the catalytic activity of [FeFe]-hydrogenase CaHydA from Clostridium acetobutylicum immobilized on negatively charged MHA-modified Au(111) electrodes [74]. Electrochemical STM showed that the apparent height of [FeFe]-hydrogenase $\mathrm{CaHydA}$ continuously increased when the potential of the STM substrate was shifted from -0.4 to $-0.6 \mathrm{~V}$ (vs. $\mathrm{Ag} / \mathrm{AgCl}$ electrode), in which the hydrogen evolution response 
was observed by CV. Notably, the catalysis of hydrogenase is easily quenched by carbon monoxide and cyanide binding to the Fe active sites.

Membrane-bound [NiFe]-hydrogenase and [NiFeSe]-hydrogenase have attracted considerable attention due to their resistance to dioxygen, carbon monoxide, as well as to high temperature [161]. Armstrong and associates reported a number of studies into the oxygen tolerance of [NiFe]-hydrogenase $[162,163]$. Typically, the catalytic sites of well-known hydrogenases are quenched by dissolved oxygen gas due to the high oxygen sensitivity of the internal peptide chains. Modification of Fe-S clusters by changing two oxygen-sensitive cysteine residues into glycines showed significant improvements in the long-term dihydrogen oxidation performance [162]. The authors demonstrated that the mechanism of oxygen tolerance mainly relates to removal of oxide species rather than preventing oxygen access into the protein. Lojou and associates demonstrated that carboxyl-terminated SAMs were favorable for optimizing the orientations of [NiFe]-hydrogenase from Aquifex aeolicus for efficient DET-type and MET-type bioelectrocatalysis of hydrogen oxidation, whereas hydrophobic SAMs only resulted in a MET process with the need for methylene blue mediator [71]. The electrochemical behavior of [NiFe]-hydrogenase from Allochromatium vinosum, DesulfoVibrio Vulgaris Miyazaki F (DvMF), and Ralstonia eutropha H16 has also been reported [164-166].

Immobilization of membrane-bound hydrogenase on the SAM-modified electrode surface appears promising, but the ET progress of membrane-bound hydrogenase is challenging due to the complex enzyme structure compared with soluble redox enzymes. Gutiérrez-Sánchez and coworkers demonstrated that the introduction of a phospholipidic bilayer on positively charged 4-ATP modified $\mathrm{Au}$ electrode surfaces effectively controls the orientation of membrane-bound [NiFeSe]-hydrogenase for hydrogen oxidation (Figure 8) [167]. The hydrophobic lipid tail of hydrogenase can be embedded into the phospholipidic bilayer, thereby reducing the orientation distribution and promoting the ET process. All these results suggest that SAM-modified electrodes are paramount to provide a versatile platform for understanding how to tune the right enzyme orientation for DET.

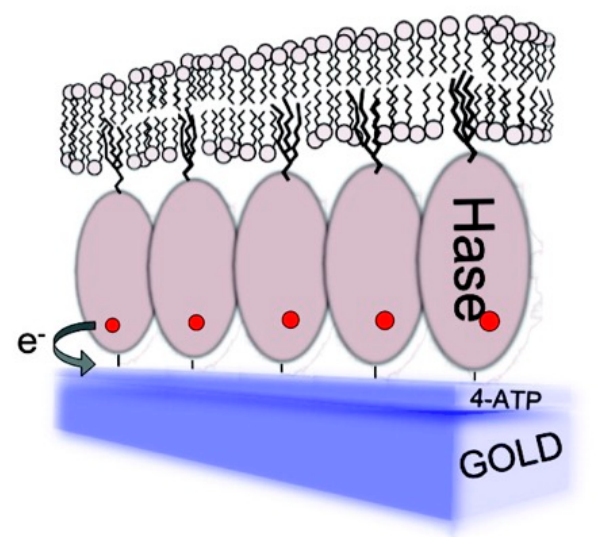

Figure 8. Schematic illustration of [NiFeSe]-hydrogenase covalently inserted into a phospholipidic bilayer. Reproduced with permission from [167]. Copyright 2011, American Chemical Society.

\section{Conclusions and Perspectives}

Redox proteins and enzymes immobilized on solid surfaces are fragile biomolecular entities. With a few exceptions, they retain ET of enzyme function only in prepared microenvironments that somehow emulate their natural aqueous/membrane reaction media. Self-assembled molecular monolayers with multifariously functionalized thiols are close to ideal SAM building blocks which have emerged as the core class over the last couple of decades. The -SH thiol end ascertains robust Au-S linking which is now increasingly well understood as dominated by the $\mathrm{Au}(0)-\bullet \mathrm{S}(0)$ gold-thiyl and strong van der Waals Au-S interaction. The opposite functionalized end of the SAM thiol molecules offers the choice of hydrophilic or hydrophobic, electrostatically charged or neutral, and structurally large or small terminal groups, well suited for designed gentle protein/enzyme linking to the solid 
SAM-modified electrochemical surface. The option of varying the length of the SAM-forming molecules offers additional control of the electron tunneling process as well as of the dielectric and other local environmental properties crucial in the overall control of the electrochemical activity of the immobilized proteins or enzymes.

We have first overviewed the preparation and comprehensive characterization of thiol-based SAMs on Au surfaces in particular, both per se and as developed in redox protein/enzyme electrochemical research over the last couple of decades. Preparation is, in principle, straightforward, although the ultimate SAM properties depend in subtle ways on thiol exposure time, temperature, and other external controlling factors. A variety of sophisticated SAM surface techniques have brought the understanding of the fundamental molecular and electronic SAM structure to a high level, ranging all the way from the ordered domain right down to the single molecule. The techniques include spectroscopy (XPS, FTIR, SPR, Raman, NEXUS, and others), microscopy (AFM, STM in the electrochemical in situ/operando modes), and mass balance techniques (QCM), supported by large-scale electronic structure calculations $[4,6,16,17,66]$.

Well-defined solid SAM-modified Au- and other electrode surfaces are a pre-requisite for the productive immobilization of bioelectrochemically active DET enzymes. An outstanding challenge is that polycrystalline $\mathrm{Au}$ - and other metallic electrodes are nearly always used, with single-crystal, atomically planar, e.g. $\mathrm{Au}(111)$, electrodes only relatively recently introduced as electrochemical biomolecular target surfaces. A variety of local low- and higher-index surface structures are distributed over the polycrystalline $\mathrm{Au}$ - and other surfaces, expectedly giving quite different surface ET activities [92]. This presents a challenge to the microscopic characterization of the pure and SAM-modified electrode surfaces but at the same time also provides new openings in the way of more robust protein/enzyme monolayers and higher enzyme activity, if the polycrystallinity can be controlled such as for NPG and other nanoporous metallic electrodes.

We have next overviewed and discussed adsorption and controlled protein and enzyme orientation on strategically chosen SAMs, of both simple ET metalloproteins (cyt. $c$ and $c_{4}$, azurin) and a variety of much more complex redox metallo- and nonmetalloenzymes (blue copper oxidases, FAD-based enzymes, cellobiose dehydrogenase, [FeS]-cluster dehydrogenases). We have shown that properly chosen SAMs can be brought to control efficiently the enzyme surface orientation in the ways most favorable both for productive bioelectrocatalysis and for detailed mapping of the molecular mechanisms involved. We have also shown that, although of more complex molecular/atomic surface structure, SAM-modified NPG and other nanoporous metallic electrochemical surfaces, structurally characterized to intermediate levels of resolution, may offer other advantages. These extend to increased enzyme stability and even enhanced catalytic efficiency compared to atomically planar electrode surfaces.

Overall, the present state of detailed structural and mechanistic protein and enzyme bioelectrochemical mapping has now advanced in impressive detail, approaching the true level of the single molecule $[3,4,6,168,169]$ and supported by large-scale electronic structure computations $[16,17,92,138]$. With new and rapidly increasing understanding of the complex, heterogeneous, and anisotropic electrode/SAM/protein/enzyme/aqueous interface, its real exploitation in the strategic design and development of enzyme biofuel cells, next-generation bioelectrochemical sensors, and other high-technology applications is rapidly coming close.

Author Contributions: Writing—original draft, X.Y.; Supervision, D.T., J.U., X.X.; Writing—review and editing, J.T., D.T., J.U., X.X. All authors have read and agreed to the published version of the manuscript.

Funding: This project has received funding from the European Union's Horizon 2020 research and innovation program under the Marie Skłodowska-Curie grant agreement No. 713683. Financial support was received also from the Danish Council for Independent Research for the YDUN project (DFF 4093-00297), the Russian Science Foundation (project No. 17-13-01274), and from Villum Experiment (grant No. 35844).

Acknowledgments: X.Y. acknowledges support from the China Scholarship Council (No. 201806650009).

Conflicts of Interest: The authors declare no conflict of interest. 


\section{References}

1. Love, J.C.; Estroff, L.A.; Kriebel, J.K.; Nuzzo, R.G.; Whitesides, G.M. Self-assembled monolayers of thiolates on metals as a form of nanotechnology. Chem. Rev. 2005, 105, 1103-1170. [CrossRef] [PubMed]

2. Nöll, T.; Nöll, G. Strategies for "wiring" redox-active proteins to electrodes and applications in biosensors, biofuel cells, and nanotechnology. Chem. Soc. Rev. 2011, 40, 3564-3576. [CrossRef] [PubMed]

3. Bollella, P. Porous Gold: A New Frontier for Enzyme-Based Electrodes. Nanomaterials 2020, 10, 722. [CrossRef] [PubMed]

4. Chi, Q.; Ford, M.J.; Halder, A.; Hush, N.S.; Reimers, J.R.; Ulstrup, J. Sulfur ligand mediated electrochemistry of gold surfaces and nanoparticles: What, how, and why. Curr. Opin. Electrochem. 2017, 1, 7-15. [CrossRef]

5. Ulman, A. Formation and structure of self-assembled monolayers. Chem. Rev. 1996, 96, 1533-1554. [CrossRef]

6. Zhang, J.; Kuznetsov, A.M.; Medvedev, I.G.; Chi, Q.; Albrecht, T.; Jensen, P.S.; Ulstrup, J. Single-molecule electron transfer in electrochemical environments. Chem. Rev. 2008, 108, 2737-2791. [CrossRef]

7. Bigelow, W.C.; Pickett, D.L.; Zisman, W.A. Oleophobic monolayers. I. Films adsorbed from solution in non-polar liquids. J. Colloid Sci. 1946, 1, 513-538. [CrossRef]

8. Nuzzo, R.G.; Allara, D.L. Adsorption of Bifunctional Organic Disulfides on Gold Surfaces. J. Am. Chem. Soc. 1983, 105, 4481-4483. [CrossRef]

9. Muskal, N.; Mandler, D. Thiol self-assembled monolayers on mercury surfaces: The adsorption and electrochemistry of v-mercaptoalkanoic acids. Electrochim. Acta 1999, 45, 537-548. [CrossRef]

10. Williams, J.A.; Gorman, C.B. Alkanethiol Reductive Desorption from Self-Assembled Monolayers on Gold, Platinum, and Palladium Substrates. J. Phys. Chem. C 2007, 111, 12804-12810. [CrossRef]

11. Hoque, E.; Derose, J.A.; Houriet, R.; Hoffmann, P.; Mathieu, H.J.; Fe, E.P. Stable Perfluorosilane Self-Assembled Monolayers on Copper Oxide Surfaces: Evidence of Siloxy-Copper Bond Formation. Chem. Mater. 2007, 19, 798-804. [CrossRef]

12. Fischer, S.; Papageorgiou, A.C.; Marschall, M.; Reichert, J.; Diller, K.; Klappenberger, F.; Allegretti, F.; Nefedov, A.; Wöll, C.; Barth, J.V. L-Cysteine on Ag(111): A combined STM and X-ray spectroscopy study of anchorage and deprotonation. J. Phys. Chem. C 2012, 116, 20356-20362. [CrossRef]

13. Alejandra, M.; Addato, F.; Rubert, A.A.; Benítez, G.A.; Fonticelli, M.H.; Carrasco, J.; Carro, P.; Salvarezza, R.C. Alkanethiol Adsorption on Platinum: Chain Length Effects on the Quality of Self-Assembled Monolayers. J. Phys. Chem. C 2011, 115, 17788-17798. [CrossRef]

14. Feliciano-ramos, I.; Caban-acevedo, M.; Scibioh, M.A.; Cabrera, C.R. Self-assembled monolayers of L-cysteine on palladium electrodes. J. Electroanal. Chem. 2010, 650, 98-104. [CrossRef]

15. Gooding, J.J.; Ciampi, S. The molecular level modification of surfaces: From self-assembled monolayers to complex molecular assemblies. Chem. Soc. Rev. 2011, 40, 2704-2718. [CrossRef]

16. Reimers, J.R.; Ford, M.J.; Marcuccio, S.M.; Ulstrup, J.; Hush, N.S. Competition of van der Waals and chemical forces on gold-sulfur surfaces and nanoparticles. Nat. Rev. Chem. 2017, 1, 1-13. [CrossRef]

17. Reimers, J.R.; Ford, M.J.; Halder, A.; Ulstrup, J.; Hush, N.S. Gold surfaces and nanoparticles are protected by $\mathrm{Au}(0)$-thiyl species and are destroyed when $\mathrm{Au}(\mathrm{I})$-thiolates form. Proc. Natl. Acad. Sci. USA 2016, 113, E1424-E1433. [CrossRef]

18. Tang, J.; Yan, X.; Engelbrekt, C.; Ulstrup, J.; Magner, E.; Xiao, X.; Zhang, J. Development of graphene-based enzymatic biofuel cells: A minireview. Bioelectrochemistry 2020, 134, 107537. [CrossRef]

19. Hitaishi, V.P.; Clement, R.; Bourassin, N.; Baaden, M.; de Poulpiquet, A.; Sacquin-Mora, S.; Ciaccafava, A.; Lojou, E. Controlling redox enzyme orientation at planar electrodes. Catalysts 2018, 8, 192. [CrossRef]

20. Milton, R.D.; Minteer, S.D. Direct enzymatic bioelectrocatalysis: Differentiating between myth and reality. J. R. Soc. Interface 2017, 14, 20170253. [CrossRef]

21. Mano, N.; De Poulpiquet, A. $\mathrm{O}_{2}$ Reduction in Enzymatic Biofuel Cells. Chem. Rev. 2018, 118, $2392-2468$. [CrossRef] [PubMed]

22. Moser, C.C.; Keske, J.M.; Warncke, K.; Farid, R.S.; Dutton, P.L. Nature of biological electron transfer. Nature 1992, 355, 796-802. [CrossRef] [PubMed]

23. Schulz, C.; Kittl, R.; Ludwig, R.; Gorton, L. Direct Electron Transfer from the FAD Cofactor of Cellobiose Dehydrogenase to Electrodes. ACS Catal. 2016, 6, 555-563. [CrossRef] 
24. Lee, H.; Lee, Y.S.; Reginald, S.S.; Baek, S.; Lee, E.M.; Choi, I.G.; Chang, I.S. Biosensing and electrochemical properties of flavin adenine dinucleotide (FAD)-Dependent glucose dehydrogenase (GDH) fused to a gold binding peptide. Biosens. Bioelectron. 2020, 165, 112427. [CrossRef]

25. Siepenkoetter, T.; Salaj-Kosla, U.; Magner, E. The Immobilization of Fructose Dehydrogenase on Nanoporous Gold Electrodes for the Detection of Fructose. ChemElectroChem 2017, 4, 905-912. [CrossRef]

26. Gutierrez-Sanchez, C.; Ciaccafava, A.; Blanchard, P.Y.; Monsalve, K.; Giudici-Orticoni, M.T.; Lecomte, S.; Lojou, E. Efficiency of Enzymatic $\mathrm{O}_{2}$ Reduction by Myrothecium verrucaria Bilirubin Oxidase Probed by Surface Plasmon Resonance, PMIRRAS, and Electrochemistry. ACS Catal. 2016, 6, 5482-5492. [CrossRef]

27. Di Bari, C.; Shleev, S.; De Lacey, A.L.; Pita, M. Laccase-modified gold nanorods for electrocatalytic reduction of oxygen. Bioelectrochemistry 2016, 107, 30-36. [CrossRef]

28. Siepenkoetter, T.; Salaj-Kosla, U.; Xiao, X.; Conghaile, P.; Pita, M.; Ludwig, R.; Magner, E. Immobilization of Redox Enzymes on Nanoporous Gold Electrodes: Applications in Biofuel Cells. ChemPlusChem 2017, 82, 553-560. [CrossRef]

29. Murata, K.; Kajiya, K.; Nakamura, N.; Ohno, H. Direct electrochemistry of bilirubin oxidase on three-dimensional gold nanoparticle electrodes and its application in a biofuel cell. Energy Environ. Sci. 2009, 2, 1280-1285. [CrossRef]

30. Adachi, T.; Kaida, Y.; Kitazumi, Y.; Shirai, O.; Kano, K. Bioelectrocatalytic performance of D-fructose dehydrogenase. Bioelectrochemistry 2019, 129, 1-9. [CrossRef]

31. Xiao, X.; Si, P.; Magner, E. An overview of dealloyed nanoporous gold in bioelectrochemistry. Bioelectrochemistry 2016, 109, 117-126. [CrossRef] [PubMed]

32. Xiao, X.; Xia, H.Q.; Wu, R.; Bai, L.; Yan, L.; Magner, E.; Cosnier, S.; Lojou, E.; Zhu, Z.; Liu, A. Tackling the Challenges of Enzymatic (Bio)Fuel Cells. Chem. Rev. 2019, 119, 9509-9558. [CrossRef] [PubMed]

33. Adachi, T.; Kitazumi, Y.; Shirai, O.; Kano, K. Direct Electron Transfer-Type Bioelectrocatalysis of Redox Enzymes at Nanostructured Electrodes. Catalysts 2020, 10, 236. [CrossRef]

34. Vaz-Dominguez, C.; Campuzano, S.; Rüdiger, O.; Pita, M.; Gorbacheva, M.; Shleev, S.; Fernandez, V.M.; De Lacey, A.L. Laccase electrode for direct electrocatalytic reduction of $\mathrm{O}_{2}$ to $\mathrm{H}_{2} \mathrm{O}$ with high-operational stability and resistance to chloride inhibition. Biosens. Bioelectron. 2008, 24, 531-537. [CrossRef]

35. Lindgren, A.; Gorton, L.; Ruzgas, T.; Baminger, U.; Haltrich, D.; Schülein, M. Direct electron transfer of cellobiose dehydrogenase from various biological origins at gold and graphite electrodes. J. Electroanal. Chem. 2001, 496, 76-81. [CrossRef]

36. Yan, Y.M.; Baravik, I.; Tel-Vered, R.; Willner, I. An ethanol/ $\mathrm{O}_{2}$ biofuel cell based on an electropolymerized bilirubin oxidase/Pt nanoparticle bioelectrocatalytic $\mathrm{O}_{2}$-reduction cathode. Adv. Mater. 2009, 21, 4275-4279. [CrossRef]

37. Schubert, K.; Goebel, G.; Lisdat, F. Bilirubin oxidase bound to multi-walled carbon nanotube-modified gold. Electrochim. Acta 2009, 54, 3033-3038. [CrossRef]

38. Climent, V.; Zhang, J.; Friis, E.P.; Østergaard, L.H.; Ulstrup, J. Voltammetry and single-molecule in situ scanning tunneling microscopy of laccases and bilirubin oxidase in electrocatalytic dioxygen reduction on $\mathrm{Au}(111)$ single-crystal electrodes. J. Phys. Chem. C 2012, 116, 1232-1243. [CrossRef]

39. Chi, Q.; Farver, O.; Ulstrup, J. Long-range protein electron transfer observed at the single-molecule level: In situ mapping of redox-gated tunneling resonance. Proc. Natl. Acad. Sci. USA 2005, 102, 16203-16208. [CrossRef]

40. Xiao, X.; Li, H.; Wang, M.; Zhang, K.; Si, P. Examining the effects of self-assembled monolayers on nanoporous gold based amperometric glucose biosensors. Analyst 2013, 139, 488-494. [CrossRef]

41. Murata, K.; Suzuki, M.; Kajiya, K.; Nakamura, N.; Ohno, H. High performance bioanode based on direct electron transfer of fructose dehydrogenase at gold nanoparticle-modified electrodes. Electrochem. Commun. 2009, 11, 668-671. [CrossRef]

42. Tominaga, M.; Ohtani, M.; Taniguchi, I. Gold single-crystal electrode surface modified with self-assembled monolayers for electron tunneling with bilirubin oxidase. Phys. Chem. Chem. Phys. 2008, 10, 6928-6934. [CrossRef] [PubMed]

43. Chi, Q.; Zhang, J.; Andersen, J.E.T.; Ulstrup, J. Ordered assembly and controlled electron transfer of the blue copper protein azurin at gold (111) single-crystal substrates. J. Phys. Chem. B 2001, 105, 4669-4679. [CrossRef] 
44. Kizling, M.; Dzwonek, M.; Więckowska, A.; Bilewicz, R. Size Does Matter-Mediation of Electron Transfer by Gold Clusters in Bioelectrocatalysis. Chem CatChem 2018, 10, 1988-1992. [CrossRef]

45. Al-Lolage, F.A.; Meneghello, M.; Ma, S.; Ludwig, R.; Bartlett, P.N. A Flexible Method for the Stable, Covalent Immobilization of Enzymes at Electrode Surfaces. ChemElectroChem 2017, 4, 1528-1534. [CrossRef]

46. Matsumura, H.; Ortiz, R.; Ludwig, R.; Igarashi, K.; Samejima, M.; Gorton, L. Direct electrochemistry of phanerochaete chrysosporium cellobiose dehydrogenase covalently attached onto gold nanoparticle modified solid gold electrodes. Langmuir 2012, 28, 10925-10933. [CrossRef]

47. Wang, X.; Falk, M.; Ortiz, R.; Matsumura, H.; Bobacka, J.; Ludwig, R.; Bergelin, M.; Gorton, L.; Shleev, S. Mediatorless sugar/oxygen enzymatic fuel cells based on gold nanoparticle-modified electrodes. Biosens. Bioelectron. 2012, 31, 219-225. [CrossRef]

48. Rauf, S.; Zhou, D.; Abell, C.; Klenerman, D.; Kang, D.J. Building three-dimensional nanostructures with active enzymes by surface templated layer-by-layer assembly. Chem. Commun. 2006, 1721-1723. [CrossRef]

49. Xiao, X.; Siepenkoetter, T.; Conghaile, P.; Leech, D.; Magner, E. Nanoporous Gold-Based Biofuel Cells on Contact Lenses. ACS Appl. Mater. Interfaces 2018, 10, 7107-7116. [CrossRef]

50. Siepenkoetter, T.; Salaj-Kosla, U.; Xiao, X.; Belochapkine, S.; Magner, E. Nanoporous Gold Electrodes with Tuneable Pore Sizes for Bioelectrochemical Applications. Electroanalysis 2016, 28, 2415-2423. [CrossRef]

51. Jensen, P.S.; Chi, Q.; Zhang, J.; Ulstrup, J. Long-Range interfacial electrochemical electron transfer of Pseudomonas aeruginosa azurin-gold nanoparticle hybrid systems. J. Phys. Chem. C 2009, 113, 13993-14000. [CrossRef]

52. Xu, S.; Han, X. A novel method to construct a third-generation biosensor: Self-assembling gold nanoparticles on thiol-functionalized poly(styrene-co-acrylic acid) nanospheres. Biosens. Bioelectron. 2004, 19, 1117-1120. [CrossRef] [PubMed]

53. Murata, K.; Suzuki, M.; Nakamura, N.; Ohno, H. Direct evidence of electron flow via the heme c group for the direct electron transfer reaction of fructose dehydrogenase using a silver nanoparticle-modified electrode. Electrochem. Commun. 2009, 11, 1623-1626. [CrossRef]

54. Gutiérrez-Sánchez, C.; Pita, M.; Vaz-Domínguez, C.; Shleev, S.; De Lacey, A.L. Gold nanoparticles as electronic bridges for laccase-based biocathodes. J. Am. Chem. Soc. 2012, 134, 17212-17220. [CrossRef]

55. Meredith, M.T.; Minteer, S.D. Biofuel Cells: Enhanced Enzymatic Bioelectrocatalysis. Annu. Rev. Anal. Chem. 2012, 5, 157-179. [CrossRef]

56. Gross, A.J.; Holzinger, M.; Cosnier, S. Buckypaper bioelectrodes: Emerging materials for implantable and wearable biofuel cells. Energy Environ. Sci. 2018, 11, 1670-1687. [CrossRef]

57. Mazurenko, I.; de Poulpiquet, A.; Lojou, E. Recent developments in high surface area bioelectrodes for enzymatic fuel cells. Curr. Opin. Electrochem. 2017, 5, 74-84. [CrossRef]

58. Mazurenko, I.; Hitaishi, V.P.; Lojou, E. Recent advances in surface chemistry of electrodes to promote direct enzymatic bioelectrocatalysis. Curr. Opin. Electrochem. 2020, 19, 113-121. [CrossRef]

59. Chaki, N.K.; Vijayamohanan, K. Self-assembled monolayers as a tunable platform for biosensor applications. Biosens. Bioelectron. 2002, 17,1-12. [CrossRef]

60. Xiao, X.; Ulstrup, J.; Li, H.; Wang, M.; Zhang, J.; Si, P. Nanoporous gold assembly of glucose oxidase for electrochemical biosensing. Electrochim. Acta 2014, 130, 559-567. [CrossRef]

61. Serleti, A.; Salaj-Kosla, U.; Magner, E. The spatial and sequential immobilisation of cytochrome c at adjacent electrodes. Chem. Commun. 2013, 49, 8395-8397. [CrossRef] [PubMed]

62. Meunier-Prest, R.; Legay, G.; Raveau, S.; Chiffot, N.; Finot, E. Potential-assisted deposition of mixed alkanethiol self-assembled monolayers. Electrochim. Acta 2010, 55, 2712-2720. [CrossRef]

63. Bradbury, C.R.; Zhao, J.; Fermín, D.J. Distance-independent charge-transfer resistance at gold electrodes modified by thiol monolayers and metal nanoparticles. J. Phys. Chem. C 2008, 112, 10153-10160. [CrossRef]

64. Chi, Q.; Zhang, J.; Arslan, T.; Borg, L.; Pedersen, G.W.; Christensen, H.E.M.; Nazmudtinov, R.R.; Ulstrup, J. Approach to interfacial and intramolecular electron transfer of the diheme protein cytochrome $c_{4}$ assembled on $\mathrm{Au}(111)$ surfaces. J. Phys. Chem. B 2010, 114, 5617-5624. [CrossRef]

65. Engelbrekt, C.; Nazmutdinov, R.R.; Zinkicheva, T.T.; Glukhov, D.V.; Yan, J.; Mao, B.; Ulstrup, J.; Zhang, J. Chemistry of cysteine assembly on $\mathrm{Au}(100)$ : Electrochemistry, in situ STM and molecular modeling. Nanoscale 2019, 11, 17235-17251. [CrossRef] 
66. Zhang, J.; Welinder, A.C.; Chi, Q.; Ulstrup, J. Electrochemically controlled self-assembled monolayers characterized with molecular and sub-molecular resolution. Phys. Chem. Chem. Phys. 2011, 13, 5526-5545. [CrossRef]

67. Hao, X.; Zhang, J.; Christensen, H.E.M.; Wang, H.; Ulstrup, J. Electrochemical single-molecule AFM of the redox metalloenzyme copper nitrite reductase in action. ChemPhysChem 2012, 13, 2919-2924. [CrossRef]

68. Marmisollé, W.A.; Capdevila, D.A.; De La Llave, E.; Williams, F.J.; Murgida, D.H. Self-assembled monolayers of $\mathrm{NH}_{2}$-terminated thiolates: Order, pKa, and specific adsorption. Langmuir 2013, 29, 5351-5359. [CrossRef]

69. Hitaishi, V.P.; Clément, R.; Quattrocchi, L.; Parent, P.; Duché, D.; Zuily, L.; Ilbert, M.; Lojou, E.; Mazurenko, I. Interplay between Orientation at Electrodes and Copper Activation of Thermus thermophilus Laccase for $\mathrm{O}_{2}$ Reduction. J. Am. Chem. Soc. 2020, 142, 1394-1405. [CrossRef]

70. Tang, J.; Werchmeister, R.M.L.; Preda, L.; Huang, W.; Zheng, Z.; Leimkühler, S.; Wollenberger, U.; Xiao, X.; Engelbrekt, C.; Ulstrup, J.; et al. Three-Dimensional Sulfite Oxidase Bioanodes Based on Graphene Functionalized Carbon Paper for Sulfite/O $\mathrm{O}_{2}$ Biofuel Cells. ACS Catal. 2019, 9, 6543-6554. [CrossRef]

71. Ciaccafava, A.; Infossi, P.; Ilbert, M.; Guiral, M.; Lecomte, S.; Giudici-Orticoni, M.T.; Lojou, E. Electrochemistry, AFM, and PM-IRRA spectroscopy of immobilized hydrogenase: Role of a hydrophobic helix in enzyme orientation for efficient $\mathrm{H}_{2}$ oxidation. Angew. Chem. Int. Ed. 2012, 51, 953-956. [CrossRef] [PubMed]

72. Loew, N.; Scheller, F.W.; Wollenberger, U. Characterization of self-assembling of glucose dehydrogenase in mono- and multilayers on gold electrodes. Electroanalysis 2004, 16, 1149-1154. [CrossRef]

73. Yehezkeli, O.; Tel-Vered, R.; Raichlin, S.; Willner, I. Nano-engineered flavin-dependent glucose dehydrogenase/gold nanoparticle-modified electrodes for glucose sensing and biofuel cell applications. ACS Nano 2011, 5, 2385-2391. [CrossRef] [PubMed]

74. Madden, C.; Vaughn, M.D.; Díez-Pérez, I.; Brown, K.A.; King, P.W.; Gust, D.; Moore, A.L.; Moore, T.A. Catalytic turnover of [FeFe]-hydrogenase based on single-molecule imaging. J. Am. Chem. Soc. 2012, 134, 1577-1582. [CrossRef]

75. Hitaishi, V.P.; Mazurenko, I.; Harb, M.; Clément, R.; Taris, M.; Castano, S.; Duché, D.; Lecomte, S.; Ilbert, M.; De Poulpiquet, A.; et al. Electrostatic-Driven Activity, Loading, Dynamics, and Stability of a Redox Enzyme on Functionalized-Gold Electrodes for Bioelectrocatalysis. ACS Catal. 2018, 8, 12004-12014. [CrossRef]

76. Guo, L.H.; Allen, H.; Hill, O. Direct electrochemistry of proteins and enzymes. Adv. Inorg. Chem. 1991, 36, 341-375. [CrossRef]

77. Albery, W.J.; Eddowes, M.J.; Allen, H.; Hill, O.; Hillman, A.R. Mechanism of the Reduction and Oxidation Reaction of Cytochrome c at a Modified Gold Electrode. J. Am. Chem. Soc. 1981, 103, 3904-3910. [CrossRef]

78. Armstrong, F.A.; Hill, H.A.O.; Walton, N.J. Direct Electrochemistry of Redox Proteins. Acc. Chem. Res. 1988, 21, 407-413. [CrossRef]

79. Armstrong, F.A.; Heering, H.A.; Hirst, J. Reaction of complex metalloproteins studied by protein-film voltammetry. Chem. Soc. Rev. 1997, 26, 169-179. [CrossRef]

80. Ma, S.; Laurent, C.V.F.P.; Meneghello, M.; Tuoriniemi, J.; Oostenbrink, C.; Gorton, L.; Bartlett, P.N.; Ludwig, R. Direct electron-transfer anisotropy of a site-specifically immobilized cellobiose dehydrogenase. ACS Catal. 2019, 9, 7607-7615. [CrossRef]

81. Bollella, P.; Hibino, Y.; Kano, K.; Gorton, L.; Antiochia, R. Highly Sensitive Membraneless Fructose Biosensor Based on Fructose Dehydrogenase Immobilized onto Aryl Thiol Modified Highly Porous Gold Electrode: Characterization and Application in Food Samples. Anal. Chem. 2018, 90, 12131-12136. [CrossRef] [PubMed]

82. Karlsson, J.J.; Nielsen, M.F.; Thuesen, M.H.; Ulstrup, J. Electrochemistry of cytochrome $c_{4}$ from Pseudomonas stutzeri. J. Phys. Chem. B 1997, 101, 2430-2436. [CrossRef]

83. Avila, A.; Gregory, B.W.; Niki, K.; Cotton, T.M. An electrochemical approach to investigate gated electron transfer using a physiological model system: Cytochrome $\mathrm{C}$ immobilized on carboxylic acid-terminated alkanethiol self-assembled monolayers on gold electrodes. J. Phys. Chem. B 2000, 104, 2759-2766. [CrossRef]

84. Wei, J.; Liu, H.; Dick, A.R.; Yamamoto, H.; He, Y.; Waldeck, D.H. Direct wiring of cytochrome c's heme unit to an electrode: Electrochemical studies. J. Am. Chem. Soc. 2002, 124, 9591-9599. [CrossRef] [PubMed]

85. Collinson, M.; Bowden, E.F.; Tarlov, M.J. Voltammetry of Covalently Immobilized Cytochrome c on Self-Assembled Monolayer Electrodes. Langmuir 1992, 8, 1247-1250. [CrossRef]

86. El Kasmi, A.; Wallace, J.M.; Bowden, E.F.; Binet, S.M.; Linderman, R.J. Controlling interfacial electron-transfer kinetics of cytochrome $c$ with mixed self-assembled monolayers. J. Am. Chem. Soc. 1998, 120, 225-226. [CrossRef] 
87. Yue, H.; Waldeck, D.H.; Schrock, K.; Kirby, D.; Knorr, K.; Switzer, S.; Rosmus, J.; Clark, R.A. Multiple sites for electron tunneling between cytochrome c and mixed self-assembled monolayers. J. Phys. Chem. C 2008, 112, 2514-2521. [CrossRef]

88. Scott, R.A.; Mauk, A.G. Cytochrome c: A Multidisciplinary Approach; Univ Science Books: Sausalito, CA, USA, 1996.

89. Jensen, P.S.; Chi, Q.; Grumsen, F.B.; Abad, J.M.; Horsewell, A.; Schiffrin, D.J.; Ulstrup, J. Gold nanoparticle assisted assembly of a heme protein for enhancement of long-range interfacial electron transfer. J. Phys. Chem. C 2007, 111, 6124-6132. [CrossRef]

90. Niki, K.; Hardy, W.R.; Hill, M.G.; Li, H.; Sprinkle, J.R.; Margoliash, E.; Fujita, K.; Tanimura, R.; Nakamura, N.; Ohno, H.; et al. Coupling to lysine-13 promotes electron tunneling through carboxylate-terminated alkanethiol self-assembled monolayers to cytochrome c. J. Phys. Chem. B 2003, 107, 9947-9949. [CrossRef]

91. Murgida, D.H.; Hildebrandt, P. Heterogeneous electron transfer of cytochrome c on coated silver electrodes. Electric field effects on structure and redox potential. J. Phys. Chem. B 2001, 105, 1578-1586. [CrossRef]

92. Shermukhamedov, A.S.; Nazmutdinov, R.R.; Zinkicheva, T.T.; Bronshtein, D.M.; Zhang, J.; Mao, B.; Tian, Z.; Yan, J.; Wu, D.-Y.; Ulstrup, J. Electronic Spillover from a Metallic Nanoparticle: Can Simple Electrochemical Electron Transfer Processes Be Catalyzed by Electronic Coupling of a Molecular Scale Gold Nanoparticle Simultaneously to the Redox Molecule and the Electrode? J. Am. Chem. Soc. 2020, 142, 10646-10658. [CrossRef] [PubMed]

93. Chazalviel, J.-N.; Allongue, P. On the Origin of the Efficient Nanoparticle Mediated Electron Transfer across a Self-Assembled Monolayer. J. Am. Chem. Soc. 2010, 133, 762-764. [CrossRef] [PubMed]

94. Engelbrekt, C.; Sørensen, K.H.; Zhang, J.; Welinder, A.C.; Jensen, P.S.; Ulstrup, J. Green synthesis of gold nanoparticles with starch-glucose and application in bioelectrochemistry. J. Mater. Chem. 2009, 19, 7839-7847. [CrossRef]

95. Della Pia, E.A.; Chi, Q.; Jones, D.D.; MacDonald, J.E.; Ulstrup, J.; Elliott, M. Single-molecule mapping of long-range electron transport for a cytochrome $b_{562}$ variant. Nano Lett. 2011, 11, 176-182. [CrossRef]

96. Dronov, R.; Kurth, D.G.; Möhwald, H.; Scheller, F.W.; Lisdat, F. Communication in a protein stack: Electron transfer between cytochrome $\mathrm{c}$ and bilirubin oxidase within a polyelectrolyte multilayer. Angew. Chem. Int. Ed. 2008, 47, 3000-3003. [CrossRef]

97. Dronov, R.; Kurth, D.G.; Möhwald, H.; Spricigo, R.; Leimkühler, S.; Wollenberger, U.; Rajagopalan, K.V.; Scheller, F.W.; Lisdat, F. Layer-by-layer arrangement by protein-protein interaction of sulfite oxidase and cytochrome c catalyzing oxidation of sulfite. J. Am. Chem. Soc. 2008, 130, 1122-1123. [CrossRef]

98. Feifel, S.C.; Kapp, A.; Lisdat, F. Electroactive nanobiomolecular architectures of laccase and cytochrome c on electrodes: Applying silica nanoparticles as artificial matrix. Langmuir 2014, 30, 5363-5367. [CrossRef]

99. Beissenhirtz, M.K.; Scheller, F.W.; Stöcklein, W.F.M.; Kurth, D.G.; Möhwald, H.; Lisdat, F. Electroactive cytochrome c multilayers within a polyelectrolyte assembly. Angew. Chem. Int. Ed. 2004, 43, 4357-4360. [CrossRef]

100. Ma, S.; Ludwig, R. Direct Electron Transfer of Enzymes Facilitated by Cytochromes. ChemElectroChem 2019, 6, 958-975. [CrossRef]

101. Bollella, P.; Hibino, Y.; Kano, K.; Gorton, L.; Antiochia, R. Enhanced Direct Electron Transfer of Fructose Dehydrogenase Rationally Immobilized on a 2-Aminoanthracene Diazonium Cation Grafted Single-Walled Carbon Nanotube Based Electrode. ACS Catal. 2018, 8, 10279-10289. [CrossRef]

102. Bollella, P.; Gorton, L.; Antiochia, R. Direct electron transfer of dehydrogenases for development of 3rd generation biosensors and enzymatic fuel cells. Sensors 2018, 18, 1319. [CrossRef] [PubMed]

103. Bollella, P.; Hibino, Y.; Kano, K.; Gorton, L.; Antiochia, R. The influence of pH and divalent/monovalent cations on the internal electron transfer (IET), enzymatic activity, and structure of fructose dehydrogenase. Anal. Bioanal. Chem. 2018, 410, 3253-3264. [CrossRef] [PubMed]

104. Hibino, Y.; Kawai, S.; Kitazumi, Y.; Shirai, O.; Kano, K. Mutation of Heme c Axial Ligands in D-Fructose Dehydrogenase For Investigation of Electron Transfer Pathways and Reduction of Overpotential in Direct Electron Transfer-type Bioelectrocatalysis. Electrochem. Commun. 2016, 67, 43-46. [CrossRef]

105. Hibino, Y.; Kawai, S.; Kitazumi, Y.; Shirai, O.; Kano, K. Construction of a protein-engineered variant of D-fructose dehydrogenase for direct electron transfer-type bioelectrocatalysis. Electrochem. Commun. 2017, 77, 112-115. [CrossRef] 
106. Sugimoto, Y.; Kawai, S.; Kitazumi, Y.; Shirai, O.; Kano, K. Function of C-terminal hydrophobic region in fructose dehydrogenase. Electrochim. Acta 2015, 176, 976-981. [CrossRef]

107. Meredith, M.T.; Minson, M.; Hickey, D.; Artyushkova, K.; Glatzhofer, D.T.; Minteer, S.D. Anthracene-modified multi-walled carbon nanotubes as direct electron transfer scaffolds for enzymatic oxygen reduction. ACS Catal. 2011, 1, 1683-1690. [CrossRef]

108. Ludwig, R.; Harreither, W.; Tasca, F.; Gorton, L. Cellobiose dehydrogenase: A versatile catalyst for electrochemical applications. ChemPhysChem 2010, 11, 2674-2697. [CrossRef]

109. Harreither, W.; Nicholls, P.; Sygmund, C.; Gorton, L.; Ludwig, R. Investigation of the pH-dependent electron transfer mechanism of ascomycetous class II cellobiose dehydrogenases on electrodes. Langmuir 2012, 28, 6714-6723. [CrossRef]

110. Scheiblbrandner, S.; Ludwig, R. Cellobiose dehydrogenase: Bioelectrochemical insights and applications. Bioelectrochemistry 2020, 131, 107345. [CrossRef]

111. Lamberg, P.; Hamit-Eminovski, J.; Toscano, M.D.; Eicher-Lorka, O.; Niaura, G.; Arnebrant, T.; Shleev, S.; Ruzgas, T. Electrical activity of cellobiose dehydrogenase adsorbed on thiols: Influence of charge and hydrophobicity. Bioelectrochemistry 2017, 115, 26-32. [CrossRef]

112. Tavahodi, M.; Ortiz, R.; Schulz, C.; Ekhtiari, A.; Ludwig, R.; Haghighi, B.; Gorton, L. Direct Electron Transfer of Cellobiose Dehydrogenase on Positively Charged Polyethyleneimine Gold Nanoparticles. ChemPlusChem 2017, 82, 546-552. [CrossRef] [PubMed]

113. Bollella, P.; Mazzei, F.; Favero, G.; Fusco, G.; Ludwig, R.; Gorton, L.; Antiochia, R. Improved DET communication between cellobiose dehydrogenase and a gold electrode modified with a rigid self-assembled monolayer and green metal nanoparticles: The role of an ordered nanostructuration. Biosens. Bioelectron. 2017, 88, 196-203. [CrossRef] [PubMed]

114. Krikstolaityte, V.; Lamberg, P.; Toscano, M.D.; Silow, M.; Eicher-Lorka, O.; Ramanavicius, A.; Niaura, G.; Abariute, L.; Ruzgas, T.; Shleev, S. Mediatorless carbohydrate/oxygen biofuel cells with improved cellobiose dehydrogenase based bioanode. Fuel Cells 2014, 14, 792-800. [CrossRef]

115. Meneghello, M.; Al-Lolage, F.A.; Ma, S.; Ludwig, R.; Bartlett, P.N. Studying Direct Electron Transfer by Site-Directed Immobilization of Cellobiose Dehydrogenase. ChemElectroChem 2019, 6, 700-713. [CrossRef]

116. Yamashita, Y.; Lee, I.; Loew, N.; Sode, K. Direct electron transfer (DET) mechanism of FAD dependent dehydrogenase complexes $\sim$ from the elucidation of intra- and inter-molecular electron transfer pathway to the construction of engineered DET enzyme complexes . Curr. Opin. Electrochem. 2018, 12, 92-100. [CrossRef]

117. Korani, A.; Salimi, A.; Karimi, B. Guanine/Ionic Liquid Derived Ordered Mesoporous Carbon Decorated with AuNPs as Efficient NADH Biosensor and Suitable Platform for Enzymes Immobilization and Biofuel Cell Design. Electroanalysis 2017, 29, 2646-2655. [CrossRef]

118. Lee, I.; Loew, N.; Tsugawa, W.; Lin, C.E.; Probst, D.; La Belle, J.T.; Sode, K. The electrochemical behavior of a FAD dependent glucose dehydrogenase with direct electron transfer subunit by immobilization on self-assembled monolayers. Bioelectrochemistry 2018, 121, 1-6. [CrossRef]

119. Xiao, X.; Conghaile, P.; Leech, D.; Ludwig, R.; Magner, E. An oxygen-independent and membrane-less glucose biobattery/supercapacitor hybrid device. Biosens. Bioelectron. 2017, 98, 421-427. [CrossRef]

120. Ito, Y.; Okuda-Shimazaki, J.; Tsugawa, W.; Loew, N.; Shitanda, I.; Lin, C.E.; La Belle, J.; Sode, K. Third generation impedimetric sensor employing direct electron transfer type glucose dehydrogenase. Biosens. Bioelectron. 2019, 129, 189-197. [CrossRef]

121. Ratautas, D.; Laurynenas, A.; Dagys, M.; Marcinkevičiene, L.; Meškys, R.; Kulys, J. High current, low redox potential mediatorless bioanode based on gold nanoparticles and glucose dehydrogenase from Ewingella americana. Electrochim. Acta 2016, 199, 254-260. [CrossRef]

122. Kim, Y.P.; Park, S.J.; Lee, D.; Kim, H.S. Electrochemical glucose biosensor by electrostatic binding of PQQ-glucose dehydrogenase onto self-assembled monolayers on gold. J. Appl. Electrochem. 2012, 42, 383-390. [CrossRef]

123. Ferapontova, E.E.; Ruzgas, T.; Gorton, L. Direct electron transfer of heme- and molybdopterin cofactor-containing chicken liver sulfite oxidase on alkanethiol-modified gold electrodes. Anal. Chem. 2003, 75, 4841-4850. [CrossRef] [PubMed] 
124. Sezer, M.; Spricigo, R.; Utesch, T.; Millo, D.; Leimkuehler, S.; Mroginski, M.A.; Wollenberger, U.; Hildebrandt, P.; Weidinger, I.M. Redox properties and catalytic activity of surface-bound human sulfite oxidase studied by a combined surface enhanced resonance Raman spectroscopic and electrochemical approach. Phys. Chem. Chem. Phys. 2010, 12, 7894-7903. [CrossRef] [PubMed]

125. Spricigo, R.; Dronov, R.; Lisdat, F.; Leimkühler, S.; Scheller, F.W.; Wollenberger, U. Electrocatalytic sulfite biosensor with human sulfite oxidase co-immobilized with cytochrome $\mathrm{c}$ in a polyelectrolyte-containing multilayer. Anal. Bioanal. Chem. 2009, 393, 225-233. [CrossRef]

126. Utesch, T.; Sezer, M.; Weidinger, I.M.; Mroginski, M.A. Adsorption of sulfite oxidase on self-assembled monolayers from molecular dynamics simulations. Langmuir 2012, 28, 5761-5769. [CrossRef]

127. Zeng, T.; Leimkühler, S.; Wollenberger, U.; Fourmond, V. Transient Catalytic Voltammetry of Sulfite Oxidase Reveals Rate Limiting Conformational Changes. J. Am. Chem. Soc. 2017, 139, 11559-11567. [CrossRef]

128. Zeng, T.; Frasca, S.; Rumschöttel, J.; Koetz, J.; Leimkühler, S.; Wollenberger, U. Role of Conductive Nanoparticles in the Direct Unmediated Bioelectrocatalysis of Immobilized Sulfite Oxidase. Electroanalysis 2016, 28, 2303-2310. [CrossRef]

129. Frasca, S.; Rojas, O.; Salewski, J.; Neumann, B.; Stiba, K.; Weidinger, I.M.; Tiersch, B.; Leimkühler, S.; Koetz, J.; Wollenberger, U. Human sulfite oxidase electrochemistry on gold nanoparticles modified electrode. Bioelectrochemistry 2012, 87, 33-41. [CrossRef]

130. Yan, J.; Frøkjær, E.; Engebrekt, C.; Leimkühler, S.; Ulstrup, J.; Wollenberger, U.; Xiao, X.; Zhang, J. Voltammetry and Single-molecule in Situ Scanning Tunnelling Microscopy of the Redox Metalloenzyme Human Sulfite Oxidase. ChemElectroChem 2020. [CrossRef]

131. Kalimuthu, P.; Belaidi, A.A.; Schwarz, G.; Bernhardt, P.V. Chitosan-Promoted Direct Electrochemistry of Human Sulfite Oxidase. J. Phys. Chem. B 2017, 121, 9149-9159. [CrossRef]

132. Khoshtariya, D.E.; Dolidze, T.D.; Shushanyan, M.; Davis, K.L.; Waldeck, D.H.; Van Eldik, R. Fundamental signatures of short- And long-range electron transfer for the blue copper protein azurin at Au/SAM junctions. Proc. Natl. Acad. Sci. USA 2010, 107, 2757-2762. [CrossRef] [PubMed]

133. Vargo, M.L.; Gulka, C.P.; Gerig, J.K.; Manieri, C.M.; Dattelbaum, J.D.; Marks, C.B.; Lawrence, N.T.; Trawick, M.L.; Leopold, M.C. Distance dependence of electron transfer kinetics for azurin protein adsorbed to monolayer protected nanoparticle film assemblies. Langmuir 2010, 26, 560-569. [CrossRef] [PubMed]

134. Zhang, J.; Chi, Q.; Hansen, A.G.; Jensen, P.S.; Salvatore, P.; Ulstrup, J. Interfacial electrochemical electron transfer in biology-Towards the level of the single molecule. FEBS Lett. 2012, 586, 526-535. [CrossRef] [PubMed]

135. Alessandrini, A.; Facci, P. Electron transfer in nanobiodevices. Eur. Polym. J. 2016, 83, 450-466. [CrossRef]

136. López-Martínez, M.; Artés, J.M.; Sarasso, V.; Carminati, M.; Díez-Pérez, I.; Sanz, F.; Gorostiza, P. Differential Electrochemical Conductance Imaging at the Nanoscale. Small 2017, 13, 1-7. [CrossRef]

137. Chin, Q.; Zhang, J.; Nielsen, J.U.; Friis, E.P.; Chorkendorff, I.; Canters, G.W.; Andersen, J.E.T.; Ulstrup, J. Molecular monolayers and interfacial electron transfer of Pseudomonas aeruginosa azurin on Au(111). J. Am. Chem. Soc. 2000, 122, 4047-4055. [CrossRef]

138. Romero-Muñiz, C.; Ortega, M.; Vilhena, J.G.; Diéz-Pérez, I.; Cuevas, J.C.; Pérez, R.; Zotti, L.A. Mechanical deformation and electronic structure of a blue copper azurin in a solid-state junction. Biomolecules 2019, 9, 506. [CrossRef]

139. Armstrong, F.A.; Barlow, N.L.; Burn, P.L.; Hoke, K.R.; Jeuken, L.J.C.; Shenton, C.; Webster, G.R. Fast, long-range electron-transfer reactions of a 'blue' copper protein coupled non-covalently to an electrode through a stilbenyl thiolate monolayer. Chem. Commun. 2004, 4, 316-317. [CrossRef]

140. Chi, Q.; Zhang, J.; Jensen, P.S.; Christensen, H.E.M.; Ulstrup, J. Long-range interfacial electron transfer of metalloproteins based on molecular wiring assemblies. Faraday Discuss. 2006, 131, 181-195. [CrossRef]

141. Zhang, J.; Welinder, A.C.; Hansen, A.G.; Christensen, H.E.M.; Ulstrup, J. Catalytic Monolayer Voltammetry and In Situ Scanning Tunneling Microscopy of Copper Nitrite Reductase on Cysteamine-Modified Au(111) Electrodes. J. Phys. Chem. B 2003, 107, 12480-12484. [CrossRef]

142. Welinder, A.C.; Zhang, J.; Hansen, A.G.; Moth-Poulsen, K.; Christensen, H.E.M.; Kuznetsov, A.M.; Bjørnholm, T.; Ulstrup, J. Voltammetry and Electrocatalysis of Achromobacter Xylosoxidans Copper Nitrite Reductase on Functionalized Au(111)-Electrode Surfaces. Z. Phys. Chem. 2007, 221, 1343-1378. [CrossRef] 
143. Tang, J.; Yan, X.; Huang, W.; Engelbrekt, C.; Duus, J.Ø.; Ulstrup, J.; Xiao, X.; Zhang, J. Bilirubin oxidase oriented on novel type three-dimensional biocathodes with reduced graphene aggregation for biocathode. Biosens. Bioelectron. 2020, 167. [CrossRef] [PubMed]

144. Xiao, X.; Leech, D.; Zhang, J. An oxygen-reducing biocathode with “oxygen tanks. " Chem. Commun. 2020, 56, 9767-9770. [CrossRef] [PubMed]

145. Lopez, F.; Siepenkoetter, T.; Xiao, X.; Magner, E.; Schuhmann, W.; Salaj-Kosla, U. Potential pulse-assisted immobilization of Myrothecium verrucaria bilirubin oxidase at planar and nanoporous gold electrodes. J. Electroanal. Chem. 2018, 812, 194-198. [CrossRef]

146. Ramírez, P.; Mano, N.; Andreu, R.; Ruzgas, T.; Heller, A.; Gorton, L.; Shleev, S. Direct electron transfer from graphite and functionalized gold electrodes to T1 and T2/T3 copper centers of bilirubin oxidase. Biochim. Biophys. Acta Bioenerg. 2008, 1777, 1364-1369. [CrossRef]

147. Lalaoui, N.; De Poulpiquet, A.; Haddad, R.; Le Goff, A.; Holzinger, M.; Gounel, S.; Mermoux, M.; Infossi, P.; Mano, N.; Lojou, E.; et al. A membraneless air-breathing hydrogen biofuel cell based on direct wiring of thermostable enzymes on carbon nanotube electrodes. Chem. Commun. 2015, 51, 7447-7450. [CrossRef]

148. Al-Lolage, F.A.; Bartlett, P.N.; Gounel, S.; Staigre, P.; Mano, N. Site-Directed Immobilization of Bilirubin Oxidase for Electrocatalytic Oxygen Reduction. ACS Catal. 2019, 9, 2068-2078. [CrossRef]

149. McArdle, T.; McNamara, T.P.; Fei, F.; Singh, K.; Blanford, C.F. Optimizing the Mass-Specific Activity of Bilirubin Oxidase Adlayers through Combined Electrochemical Quartz Crystal Microbalance and Dual Polarization Interferometry Analyses. ACS Appl. Mater. Interfaces 2015, 7, 25270-25280. [CrossRef]

150. Gholami, F.; Navaee, A.; Salimi, A.; Ahmadi, R.; Korani, A.; Hallaj, R. Direct Enzymatic Glucose/O $\mathrm{O}_{2}$ Biofuel Cell based on Poly-Thiophene Carboxylic Acid alongside Gold Nanostructures Substrates Derived through Bipolar Electrochemistry. Sci. Rep. 2018, 8, 1-14. [CrossRef]

151. Yang, S.; Liu, J.; Quan, X.; Zhou, J. Bilirubin Oxidase Adsorption onto Charged Self-Assembled Monolayers: Insights from Multiscale Simulations. Langmuir 2018, 34, 9818-9828. [CrossRef]

152. Pankratov, D.; Sundberg, R.; Suyatin, D.B.; Sotres, J.; Barrantes, A.; Ruzgas, T.; Maximov, I.; Shleev, S. The influence of nanoparticles on enzymatic bioelectrocatalysis. RSC Adv. 2014, 4, 38164-38168. [CrossRef]

153. Cabrita, J.F.; Abrantes, L.M.; Viana, A.S. N-Hydroxysuccinimide-terminated self-assembled monolayers on gold for biomolecules immobilisation. Electrochim. Acta 2005, 50, 2117-2124. [CrossRef]

154. Balland, V.; Hureau, C.; Cusano, A.M.; Liu, Y.; Tron, T.; Limoges, B. Oriented immobilization of a fully active monolayer of histidine-tagged recombinant laccase on modified gold electrodes. Chem. A Eur. J. 2008, 14, 7186-7192. [CrossRef] [PubMed]

155. Pita, M.; Gutierrez-Sanchez, C.; Olea, D.; Velez, M.; Garcia-Diego, C.; Shleev, S.; Fernandez, V.M.; Lacey, A.L.D. High redox potential cathode based on laccase covalently attached to gold electrode. J. Phys. Chem. C 2011, 115, 13420-13428. [CrossRef]

156. Shleev, S.; Christenson, A.; Serezhenkov, V.; Burbaev, D.; Yaropolov, A.; Gorton, L.; Ruzgas, T. Electrochemical redox transformations of $\mathrm{T} 1$ and $\mathrm{T} 2$ copper sites in native Trametes hirsuta laccase at gold electrode. Biochem. J. 2005, 385, 745-754. [CrossRef]

157. Thorum, M.S.; Anderson, C.A.; Hatch, J.J.; Campbell, A.S.; Marshall, N.M.; Zimmerman, S.C.; Lu, Y.; Gewirth, A.A. Direct, electrocatalytic oxygen reduction by laccase on anthracene-2-methanethiol-modified gold. J. Phys. Chem. Lett. 2010, 1, 2251-2254. [CrossRef]

158. Traunsteiner, C.; Sek, S.; Huber, V.; Valero-Vidal, C.; Kunze-Liebhäuser, J. Laccase immobilized on a mixed thiol monolayer on $\mathrm{Au}(111)$-Structure-dependent activity towards oxygen reduction. Electrochim. Acta 2016, 213, 761-770. [CrossRef]

159. Hakamada, M.; Takahashi, M.; Mabuchi, M. Enhanced thermal stability of laccase immobilized on monolayer-modified nanoporous Au. Mater. Lett. 2012, 66, 4-6. [CrossRef]

160. Krassen, H.; Stripp, S.T.; Böhm, N.; Berkessel, A.; Happe, T.; Ataka, K.; Heberle, J. Tailor-made modification of a gold surface for the chemical binding of a high-activity [FeFe] hydrogenase. Eur. J. Inorg. Chem. 2011, 1138-1146. [CrossRef]

161. Gutiérrez-Sanz, Ó.; Tapia, C.; Marques, M.C.; Zacarias, S.; Vélez, M.; Pereira, I.A.C.; De Lacey, A.L. Induction of a Proton Gradient across a Gold-Supported Biomimetic Membrane by Electroenzymatic $\mathrm{H}_{2}$ Oxidation. Angew. Chem. 2015, 127, 2722-2725. [CrossRef] 
162. Goris, T.; Wait, A.F.; Saggu, M.; Fritsch, J.; Heidary, N.; Stein, M.; Zebger, I.; Lendzian, F.; Armstrong, F.A.; Friedrich, B.; et al. A unique iron-sulfur cluster is crucial for oxygen tolerance of a [NiFe]-hydrogenase. Nat. Chem. Biol. 2011, 7, 310-318. [CrossRef] [PubMed]

163. Cracknell, J.A.; Wait, A.F.; Lenz, O.; Friedrich, B.; Armstrong, F.A. A kinetic and thermodynamic understanding of $\mathrm{O}_{2}$ tolerance in [NiFe]-hydrogenases. Proc. Natl. Acad. Sci. USA 2009, 106, 20681-20686. [CrossRef] [PubMed]

164. Sezer, M.; Frielingsdorf, S.; Millo, D.; Heidary, N.; Utesch, T.; Mroginski, M.A.; Friedrich, B.; Hildebrandt, P.; Zebger, I.; Weidinger, I.M. Role of the HoxZ subunit in the electron transfer pathway of the membrane-bound [NiFe]-hydrogenase from Ralstonia eutropha immobilized on electrodes. J. Phys. Chem. B 2011, 115, 10368-10374. [CrossRef] [PubMed]

165. Millo, D.; Pandelia, M.E.; Utesch, T.; Wisitruangsakul, N.; Mroginski, M.A.; Lubitz, W.; Hildebrandt, P.; Zebger, I. Spectroelectrochemical study of the [NiFe] hydrogenase from Desulfovibrio vulgaris miyazaki F in solution and immobilized on biocompatible gold surfaces. J. Phys. Chem. B 2009, 113, 15344-15351. [CrossRef]

166. Léger, C.; Jones, A.K.; Albracht, S.P.J.; Armstrong, F.A. Effect of a dispersion of interfacial electron transfer rates on steady state catalytic electron transport in [NiFe]-hydrogenase and other enzymes. J. Phys. Chem. B 2002, 106, 13058-13063. [CrossRef]

167. Gutiérrez-Sánchez, C.; Olea, D.; Marques, M.; Fernández, V.M.; Pereira, I.A.C.; Vélez, M.; Lacey, A.L.D. Oriented immobilization of a membrane-bound hydrogenase onto an electrode for direct electron transfer. Langmuir 2011, 27, 6449-6457. [CrossRef]

168. Zhang, B.; Song, W.; Pang, P.; Lai, H.; Chen, Q.; Zhang, P.; Lindsay, S. Role of contacts in long-range protein conductance. Proc. Natl. Acad. Sci. USA 2019, 116, 5886-5891. [CrossRef]

169. Lagunas, A.; Guerra-Castellano, A.; Nin-Hill, A.; Díaz-Moreno, I.; De la Rosa, M.A.; Samitier, J.; Rovira, C.; Gorostiza, P. Long distance electron transfer through the aqueous solution between redox partner proteins. Nat. Commun. 2018, 9,3-9. [CrossRef]

Publisher's Note: MDPI stays neutral with regard to jurisdictional claims in published maps and institutional affiliations.

(C) 2020 by the authors. Licensee MDPI, Basel, Switzerland. This article is an open access article distributed under the terms and conditions of the Creative Commons Attribution (CC BY) license (http://creativecommons.org/licenses/by/4.0/). 